Letter Report

\title{
Yucca Mountain Environmental Monitoring Systems Initiative \\ Air Quality Scoping Study for Caliente, Lincoln County, Nevada
}

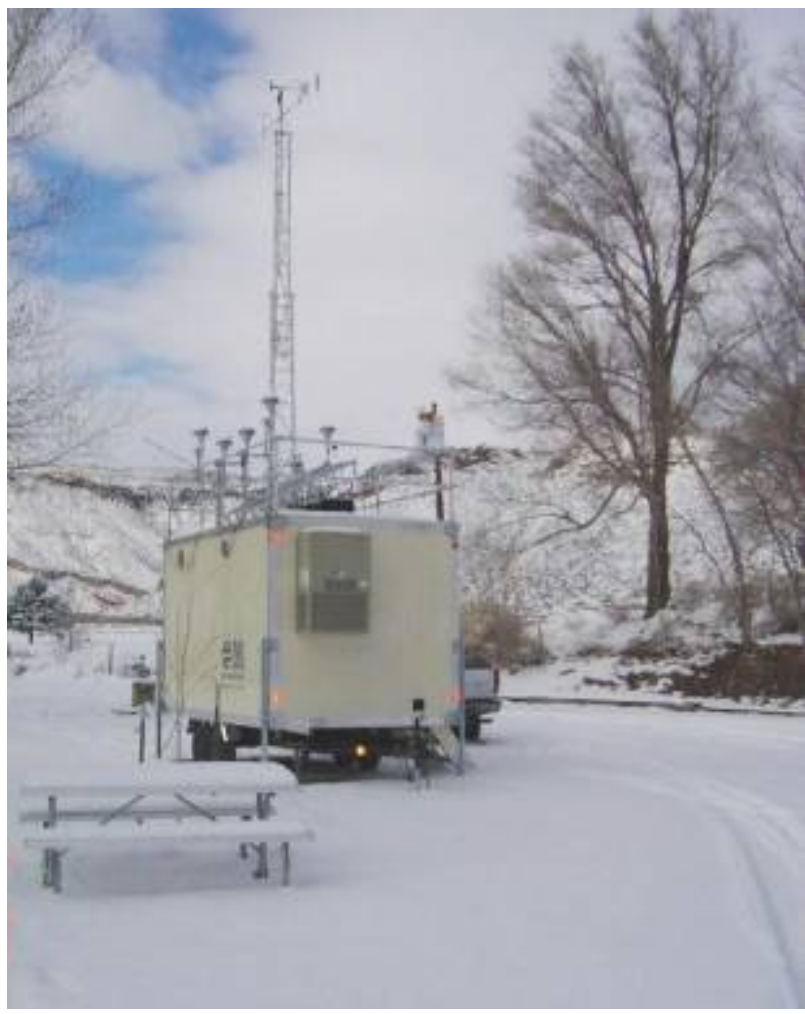

prepared by

Johann Engelbrecht, Ilias Kavouras, Dave Campbell, Scott Campbell, Steven Kohl and David Shafer Desert Research Institute

Nevada System of Higher Education

\author{
submitted to \\ Nevada Site Office \\ National Nuclear Security Administration \\ U.S. Department of Energy \\ Las Vegas, Nevada
}

August 2008

The work upon which this report is based was supported by the U.S. Department of Energy under Contract \#DE-AC52-06NA26383. 
Reference herein to any specific commercial product, process, or service by trade name, trademark, manufacturer, or otherwise, does not necessarily constitute or imply its endorsement, recommendation, or favoring by the United States Government or any agency thereof or its contractors or subcontractors. The views and opinions of authors expressed herein do not necessarily state or reflect those of the United States Government of any agency thereof.

This report has been reproduced directly from the best available copy.

Available for sale to the public, if paper, from:

\author{
U.S. Department of Commerce \\ National Technical Information Service \\ 5285 Port Royal Road \\ Springfield, VA 22161 \\ Phone: 800.553.6847 \\ Fax: 703.605.6900 \\ Email: orders@ntis.gov \\ Online ordering: http://www.ntis.gov/ordering.htm
}

Available electronically at http://www.osti.gov/bridge.

Available for a processing fee to the U.S. Department of Energy and its contractors, in paper, from:

U.S. Department of Energy

Office of Scientific and Technical Information

P.O. Box 62

Oak Ridge, TN 37831-0062

Phone: 865.576.8401

Fax: 865.576.5728

Email: reports@adonis.osti.gov 


\section{Erata Sheet}

\section{Yucca Mountain Environmental Monitoring Systems Initiative Air Quality Scoping Study for Caliente, Lincoln County, Nevada}

Page 3, 4th line from the bottom, date should read December 5, 2006

Page 21, caption should read: Figure 22. Wind direction and speed (mph) at Caliente.

Page 24, last para, last sentence should read: This may be explained by water-bound clay and organic particles.

\section{Yucca Mountain Environmental Monitoring Systems Initiative Air Quality Scoping Study for Crater Flat, Nye County, Nevada}

Page 6, Table 3, line 12, should be $\mathrm{Ca}^{2+}$

Page 18, caption should read: Figure 18. Wind direction and speed (mph) at Crater Flat.

Page 21, first paragraph line 6, date should be July 29, 2007

\section{Yucca Mountain Environmental Monitoring Systems Initiative Air Quality Scoping Study for Pahranagat National Wildlife Refuge, Lincoln County, Nevada}

Page 3, third line from bottom, date should read February 17, 2007 Page 6, Table 3, line 12, should be $\mathrm{Ca}^{2+}$

Page 21, caption should read: Figure 22. Wind direction and speed (mph) at Pahranagat NWR.

Page 22, line 9 should read: southeasterly and northerly winds (Figure 25 and Figure 26).

\section{Yucca Mountain Environmental Monitoring Systems Initiative Air Quality Scoping Study for Tonopah Airport, Nye County, Nevada}

Page 10, $3^{\text {rd }}$ line from the bottom, date should read August 29, 2007 Page 7, Table 3, line 5, should be $\mathrm{Ca}^{2+}$

Page 21, caption should read: Figure 22. Wind direction and speed (mph) at Tonopah Airport. 
THIS PAGE INTENTIONALLY LEFT BLANK 


\section{CONTENTS}

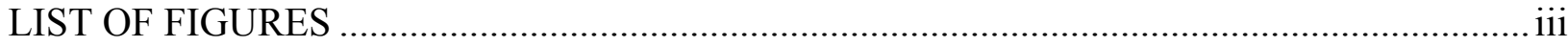

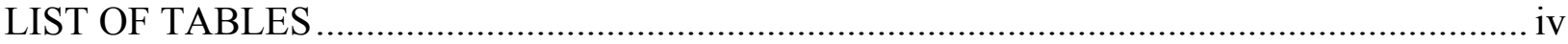

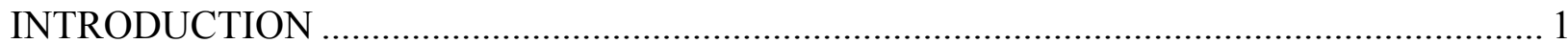

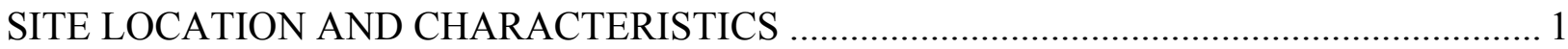

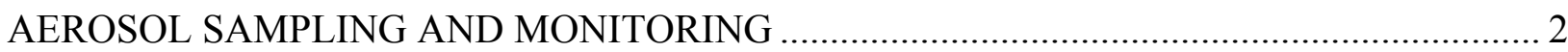

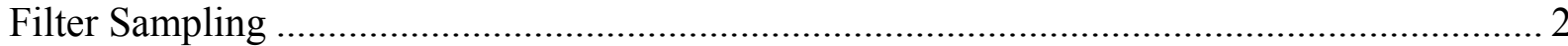

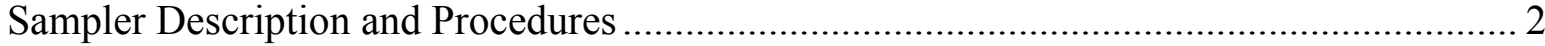

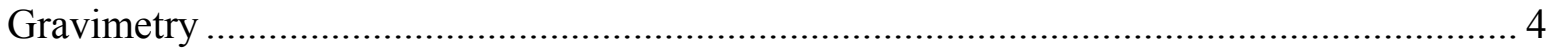

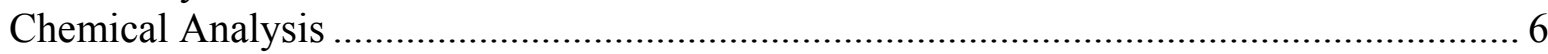

Aerosol Monitoring .................................................................................................. 9

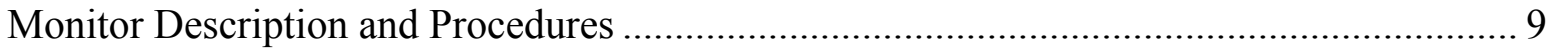

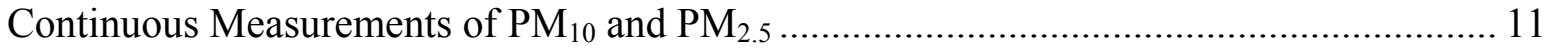

Comparison of Filter to Continuous Results................................................................... 16

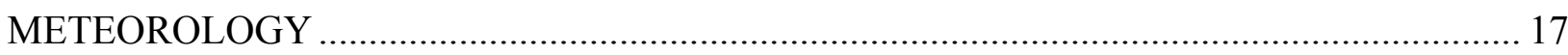

Associations of Meteorology with Aerosol Measurements ...................................................... 22

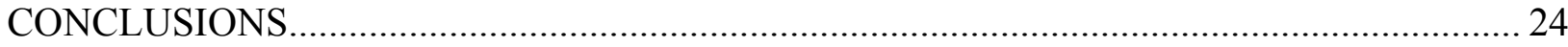

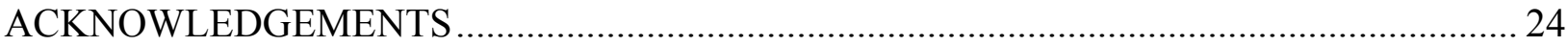

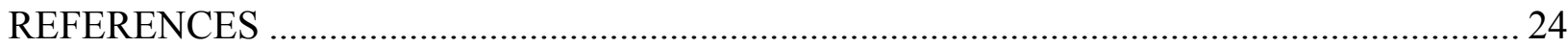

\section{LIST OF FIGURES}

1. Southern Nevada map showing the location of Site \#5 (at Caliente), Nevada Test Site, and Yucca Mountain.

2. Photographs of PQ100 (green/gray box in left photo), PQ200 (white box in left photo)

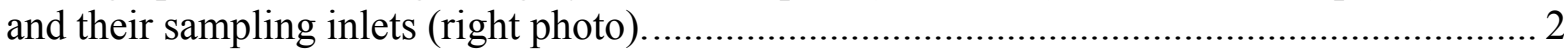

3. A diagrammatic representation of the $\mathrm{BGI} \mathrm{PM}_{2.5}$ sampler showing the $\mathrm{PM}_{10}$ size selective impactor head as the first stage followed by a $\mathrm{PM}_{2.5}$ VSCC. ……….................................... 3

4. Time series of $\mathrm{PM}_{10}$ and $\mathrm{PM}_{2.5}$ mass concentrations ( \pm uncertainty) at Site $\# 5$ (Caliente)...... 5

5. Relationship between mean ( \pm uncertainty) daily $\mathrm{PM}_{2.5}$ and $\mathrm{PM}_{10}$ at Caliente....................... 5

6. Reconstructed mass for $\mathrm{PM}_{10}$ and $\mathrm{PM}_{2.5}$ based on chemical composition. ............................. 9

7. Left photograph: The front panels of $\mathrm{PM}_{10}$ (right on the left photograph) and $\mathrm{PM}_{2.5}$ (left on the left photograph) of TEOM. Right photograph: The DustTrak monitors (green)

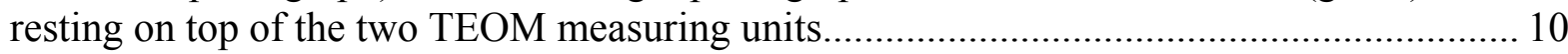

8. Schematic drawing of the sampling inlet for DUSTTRAK (not to scale).............................. 11

9. Mean 24-h $\mathrm{PM}_{10}$ and $\mathrm{PM}_{2.5}$ mass concentrations measured by TEOM at Site \#5 (Caliente)

10. $\mathrm{PM}_{2.5} / \mathrm{PM}_{10}$ mass ratios measured by TEOM at Site \#5 (Caliente). ....................................... 13

11. Variation of mean ( \pm st.error) $\mathrm{PM}_{10}$ and $\mathrm{PM}_{2.5}\left(\mu \mathrm{g} / \mathrm{m}^{3}\right)$ in weekdays and weekends at Site \#5 (Caliente) (Monday $=1$, Tuesday $=2$, Wednesday $=3$, Thursday $=4$, Friday $=5$, Saturday $=6$, Sunday $=7$ ).

12. $\mathrm{PM}_{10}$ mass $\left(\mu \mathrm{g} / \mathrm{m}^{3}\right)$ measured with DUSTTRAK and TEOM at Site \#5 (Caliente)................ 14 
13. $\mathrm{PM}_{2.5}$ mass $\left(\mu \mathrm{g} / \mathrm{m}^{3}\right)$ measured with DUSTTRAK and TEOM at Site \#5 (Caliente)....

14. Comparison of 24-h $\mathrm{PM}_{10}$ and $\mathrm{PM}_{2.5}$ mass concentrations measured by TEOM and DUSTTRAK....

15. Relationships between $\mathrm{PM}_{10}$ concentrations $\left(\mu \mathrm{g} / \mathrm{m}^{3}\right)$ measured by TEOM, DUSTTRAK, and filter-based methods.

16. Relationships between $\mathrm{PM}_{2.5}$ concentrations $\left(\mu \mathrm{g} / \mathrm{m}^{3}\right)$ measured by TEOM, DUSTTRAK, and filter-based methods.

17. Solar radiation (in watts $/ \mathrm{m}^{2}$ ) at Site \#5 (Caliente)....

18. Temperature (in ${ }^{\circ} \mathrm{F}$ ) and relative humidity at Site $\# 5$ (Caliente)....................................... 18

19. Precipitation (in $\mathrm{mm}$ ) and relative humidity at Site \#5 (Caliente).................................... 19

20. Wind speed (in miles/hr) at Site \#5 (Caliente)................................................................ 19

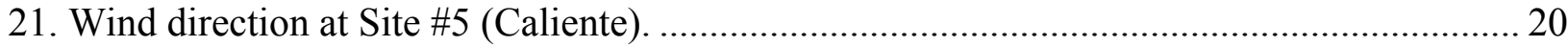

22. Wind direction and speed at Caliente. ...................................................................... 21

23. Average wind speed for each wind direction sector................................................... 21

24. Hourly variation of $\mathrm{PM}_{10}$ and $\mathrm{PM}_{2.5}$ mass concentrations $\left(\mu \mathrm{g} / \mathrm{m}^{3}\right)$ as well as wind speed (miles/hour) at Site \#5 (Caliente)............................................................................. 22

25. Mean ( \pm st.error) of $\mathrm{PM}_{10}$ mass concentrations $\left(\mu \mathrm{g} / \mathrm{m}^{3}\right)$ for different wind direction sectors at Site \#5 (Caliente). ................................................................................ 23

26. Mean ( \pm st.error) of $\mathrm{PM}_{2.5}$ mass concentrations $\left(\mu \mathrm{g} / \mathrm{m}^{3}\right)$ for different wind direction

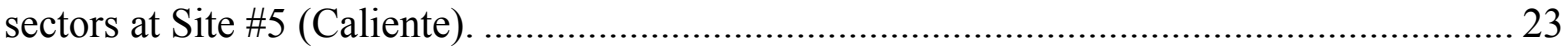

\section{LIST OF TABLES}

1. Longitude, latitude, and elevation of the mobile trailer location at Site \#5 (Caliente)............ 2

2. Collection day, filter number, mass, and uncertainty determined by gravimetric analysis, and associated flags of samples from Site \#5 (Caliente). ............................................... 4

3. Results of the chemical analysis for selected filters from Caliente. .............................. 6

4. Statistics for 24-h $\mathrm{PM}_{10}$ and $\mathrm{PM}_{2.5}$ TEOM mass concentrations. ....................................... 11

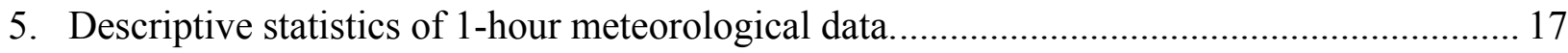

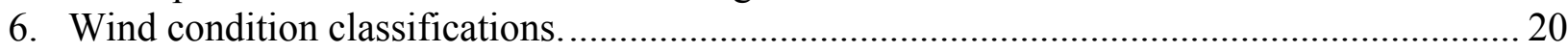




\section{INTRODUCTION}

The Desert Research Institute (DRI) is performing a scoping study as part of the U.S. Department of Energy's Yucca Mountain Environmental Monitoring Systems Initiative (EMSI). The main objective is to obtain baseline air quality information for Yucca Mountain and an area surrounding the Nevada Test Site (NTS).

Air quality and meteorological monitoring and sampling equipment housed in a mobile trailer (shelter) is collecting data at eight sites outside the NTS, including Ash Meadows National Wildlife Refuge (NWR), Beatty, Sarcobatus Flats, Rachel, Caliente, Pahranagat NWR, Crater Flat, and Tonopah Airport, and at four sites on the NTS (Engelbrecht et al., 2007a-d). The trailer is stationed at any one site for approximately eight weeks at a time.

This letter report provides a summary of air quality and meteorological data, on completion of the site's sampling program.

\section{SITE LOCATION AND CHARACTERISTICS}

Caliente is located at the junction of the Meadow Valley and Clover washes in Lincoln County, Nevada (3736 $55^{\prime \prime} \mathrm{N}, 114^{\circ} 30^{\prime} 51^{\prime \prime} \mathrm{W}$ at 4,406 feet in elevation). The population of Caliente is 1,123 inhabitants. It is located about 120 miles northeast of the Yucca Mountain Repository facility (Figure 1) and about 105 miles northeast of Las Vegas along Interstate-93. The climate is characterized by hot summers, cool winters, and less than 20 inches of precipitation (both rain and snowfall) annually.

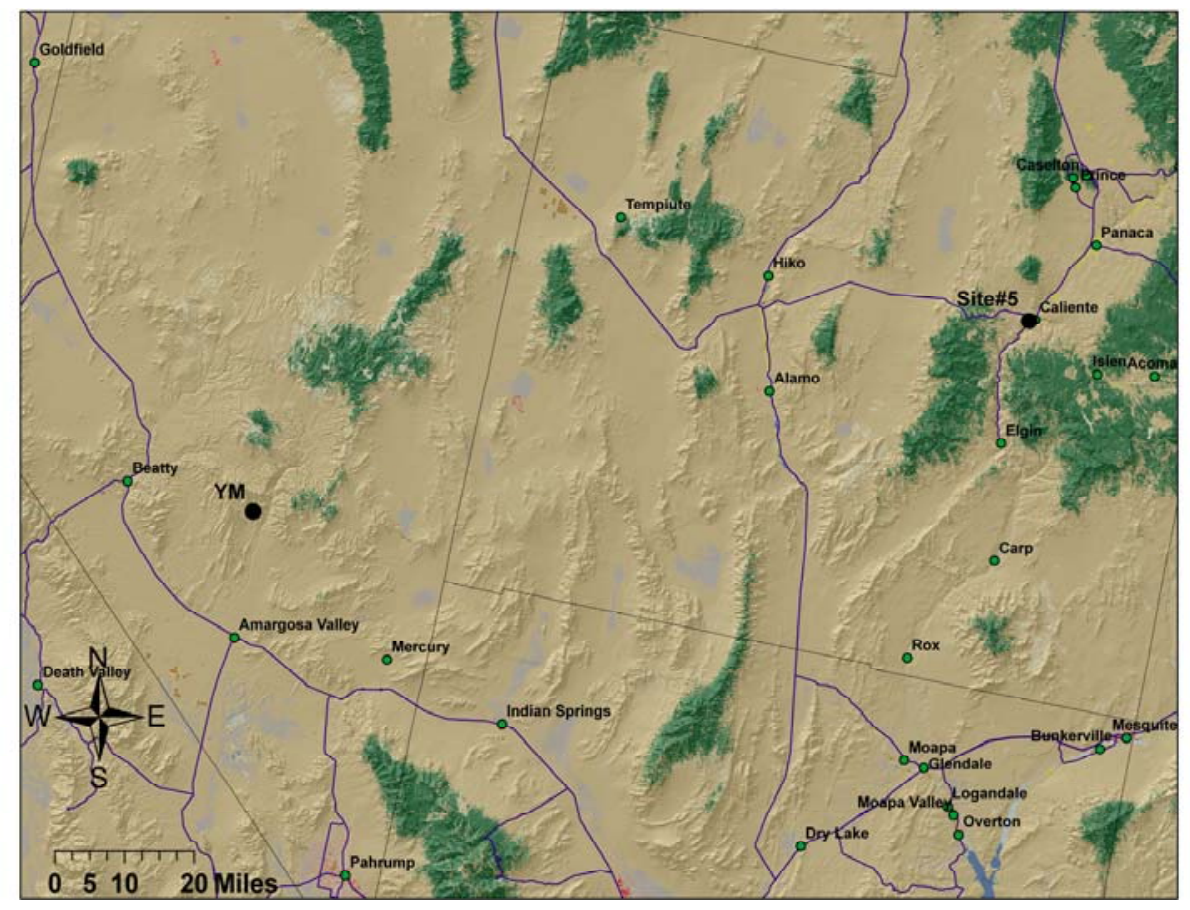

Figure 1. Southern Nevada map showing the location of Site \#5 (at Caliente), Nevada Test Site, and Yucca Mountain. The map background is land use and land cover from the 2001 National Land Cover Database. 
The mobile trailer was located on the edge of an RV trailer park on the south end of Caliente. Monitoring of $\mathrm{PM}_{10}, \mathrm{PM}_{2.5}$, and meteorological conditions was carried out from December 05, 2006, to February 15, 2007. A Nevada Department of Transportation regional office and parking lot for heavy equipment was located about 200 feet northeast of the site.

Table 1. Longitude, latitude, and elevation of the mobile trailer location at Site \#5 (Caliente).

\begin{tabular}{cc}
\hline Site & Caliente \\
\hline Latitude & $37^{\circ} 63^{\prime} 43.57^{\prime \prime}$ \\
Longitude & $114^{\circ} 31,36.60^{\prime \prime}$ \\
\hline
\end{tabular}

\section{AEROSOL SAMPLING AND MONITORING}

\section{Filter Sampling}

\section{$\underline{\text { Sampler Description and Procedures }}$}

BGI, Inc., PQ100 and PQ200 Ambient PM 2.5 Federal Reference Method (FRM) samplers were used to collect 24-h integrated $\mathrm{PM}_{10}$ and $\mathrm{PM}_{2.5}$ samples. Figure 2 shows the PQ100 and PQ200 in the mobile trailer (left) and the $\mathrm{PM}_{10}$ sampling inlets on the top of the trailer (right). Both PQ100 (Designation No. RFPS-1298-124) and PQ200 (Designation No. RFPS-0498-116) are designed to meet the criteria for collecting 24-h samples of ambient aerosol according to the U.S. National Ambient Air Quality Standards (NAAQS).

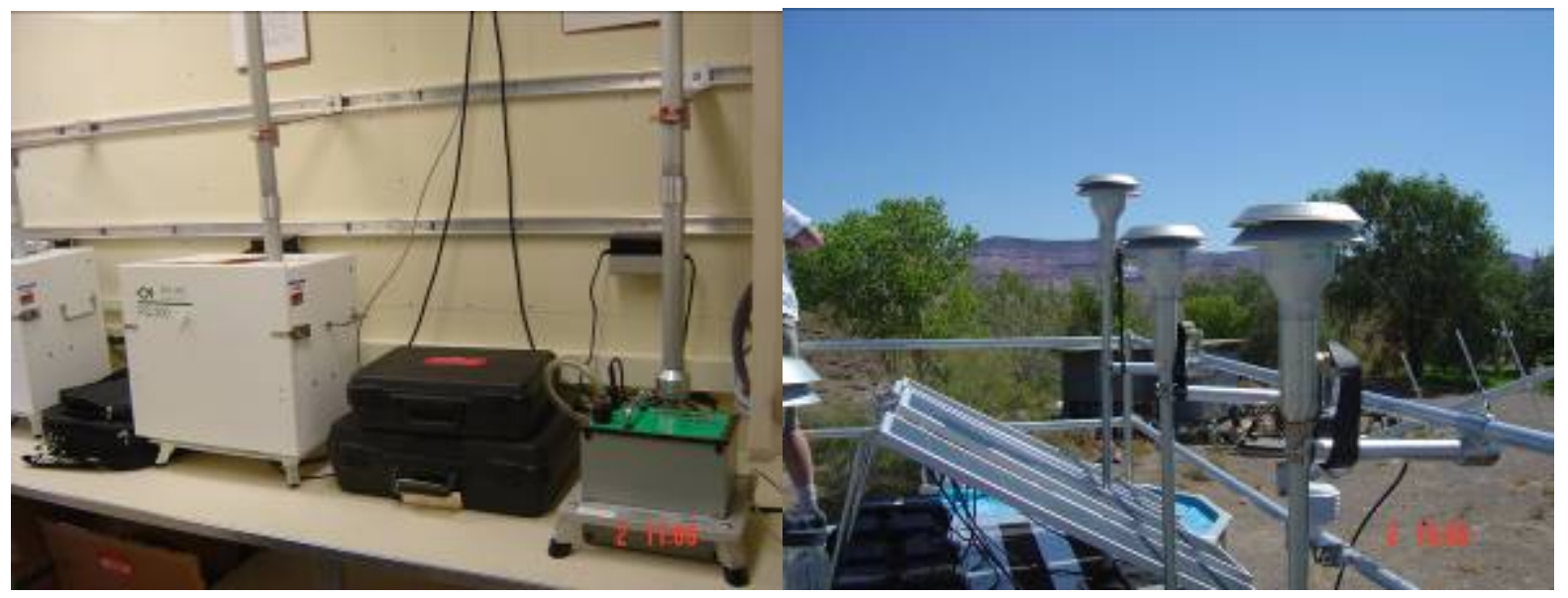

Figure 2. Photographs of PQ100 (green/gray box in left photo), PQ200 (white box in left photo) and their sampling inlets (right photo).

Figure 3 shows a schematic drawing of the samplers. Particles with aerodynamic diameter larger than $10 \mu \mathrm{m}$ are removed by impaction by the size selective inlet, while the smaller particles remain airborne. The $\mathrm{PM}_{10}$ fraction is collected by a filter located downstream of the size selective inlet. For the collection of $\mathrm{PM}_{2.5}$, particles in the range between 2.5 and $10 \mu \mathrm{m}$ were removed by the Very Sharp Cut Cyclone (VSCC) (U.S. 
Environmental Protection Agency [EPA] Equivalent Designation No. EQPM-0202-142), then collected on a filter.

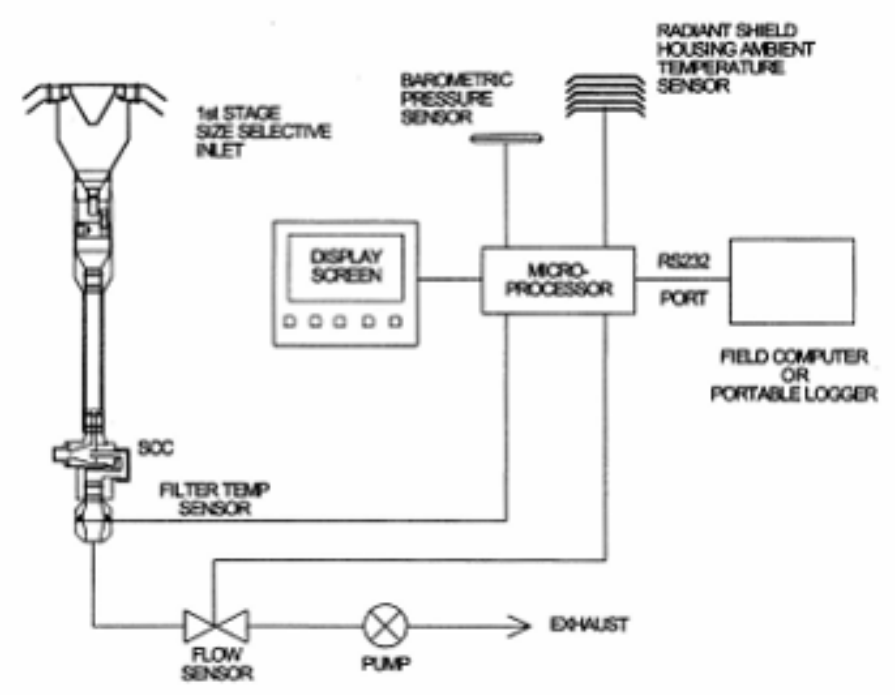

Figure 3. A diagrammatic representation of the $\mathrm{BGI} \mathrm{PM}_{2.5}$ sampler showing the $\mathrm{PM}_{10}$ size selective impactor head as the first stage followed by a $\mathrm{PM}_{2.5}$ VSCC. This configuration can be readily modified to a $\mathrm{PM}_{10}$ sampler by removal of the VSCC.

For both PQ100 and PQ200, samples were collected at a volumetric flow rate of 16.67 liters $/ \mathrm{min}$. The flow rate is controlled to \pm 2 percent precision with a mass flow controller. The actual ambient temperature and barometric pressure, filter temperature and pressure, and anomalies (if any) were recorded by a microprocessor. The sampler was equipped to operate from an internal 12 -volt DC battery. The battery was normally recharged from 120-volt AC. Alternatively, a 32-watt solar panel with an additional external ballast battery was installed to provide power for periods without electricity. Two sets of PQ100 and PQ200 samplers were installed in the mobile trailer. $\mathrm{PM}_{10}$ and $\mathrm{PM}_{2.5}$ samples were collected on filters in numbered cassettes, labeled TT (for $\mathrm{PM}_{10}$ Teflon), FT (for $\mathrm{PM}_{2.5}$ Teflon), TQ (for $\mathrm{PM}_{10}$ Quartz), and FQ (for $\mathrm{PM}_{2.5}$ Quartz). Each filter cassette was loaded with a preweighed 46.2-mm-diameter PTFE (Teflon) membrane filter (Whatman \# 7592-004) or 47mm quartz fiber (Pallflex \#2500QAT-UP) filter. The Teflon membrane collected particles for gravimetric analysis, light absorption by densitometry, and elements by X-ray fluorescence spectrometry. Quartz fiber filters were used for measurement of water-soluble ions by atomic absorption spectrometry, ion chromatography, and automated colorimetry, and also for measurement of carbon species by thermal optical reflectance.

Operation, calibration, and maintenance of PQ100 and PQ200 particulate samplers are described in standard operating procedure DRI SOP \# 1-211.2 "BGI PQ100 PM10 and PQ200 PM2.5 REFERENCE SAMPLERS FOR THE YUCCA MOUNTAIN AIR QUALITY PROGRAM." Flow calibration and leak tests (only for PQ200) were performed on the day of installation (May 25, 2007). The leak check was performed according to the manufacturer's operational instruction manual only for PQ200; no procedure is proposed by the manufacturer for the PQ100. The flow rates were set according to a BGI Tri-Cal NIST traceable standard. The sampler was then placed in "calibration" or "run" mode and a one- 
point calibration verification or one-point flow-rate verification performed. Aerosol samples were collected on a 1-in-6-day schedule. Audits of the flow and leak tests were done onsite at the beginning and end of the monitoring campaign. Teflon and quartz filters were prepared and assembled in their filter holders by the Desert Research Institute's (DRI) Environmental Analysis Facility (EAF) in Reno and shipped to DRI's facilities in Las Vegas. The filters were kept at $-4^{\circ} \mathrm{C}$ and transported to the field in a cryo-cooler. Exposed filters were also stored at $-4^{\circ} \mathrm{C}$ in Las Vegas. Upon completion of the monitoring period at the site, all filters were shipped to the EAF in Reno.

\section{Gravimetry}

Table 2 shows mass concentrations (and uncertainty) of filters collected at Caliente. $\mathrm{PM}_{10}$ mass concentrations varied from $3.16 \mu \mathrm{g} / \mathrm{m}^{3}$ to $31.41 \mu \mathrm{g} / \mathrm{m}^{3}$, while $\mathrm{PM}_{2.5}$ mass concentrations ranged from $1.87 \mu \mathrm{g} / \mathrm{m}^{3}$ to $8.74 \mu \mathrm{g} / \mathrm{m}^{3}$. Similar temporal trends were observed for both $\mathrm{PM}_{10}$ and $\mathrm{PM}_{2.5}$. In all cases, 24-h $\mathrm{PM}_{10}$ and $\mathrm{PM}_{2.5}$ levels were significantly lower than the daily and annual NAAQS as recently revised by EPA $\left(24-\mathrm{h}\right.$ PM $_{10}: 150 \mu \mathrm{g} / \mathrm{m}^{3}, 24-\mathrm{h}$ $\mathrm{PM}_{2.5}: 35 \mu \mathrm{g} / \mathrm{m}^{3}$; Annual $\mathrm{PM}_{2.5}: 15 \mu \mathrm{g} / \mathrm{m}^{3}$ ) (Figure 4). On, average, fine particles $\left(\mathrm{PM}_{2.5}\right)$ accounted for approximately one-third of $\mathrm{PM}_{10}\left(\mathrm{PM}_{2.5} / \mathrm{PM}_{10}\right.$ ratio of 0.35$)$ (Figure 5). The chemical analysis of Teflon and quartz filters will provide more information on the origin of coarse particles.

Table 2. Collection day, filter number, mass, and uncertainty determined by gravimetric analysis, and associated flags of samples from Site \#5 (Caliente).

\begin{tabular}{|c|c|c|c|c|c|}
\hline Date & No & Type & $\begin{array}{c}\text { Mass } \\
\left(\mu \mathrm{g} / \mathrm{m}^{3}\right)\end{array}$ & $\begin{array}{c}\text { Uncertainty } \\
\left(\mu \mathrm{g} / \mathrm{m}^{3}\right)\end{array}$ & Flags \\
\hline \multirow{2}{*}{$12 / 7 / 2006$} & \multirow{2}{*}{057} & $\mathrm{PM}_{10}$ & 31.4132 & 0.7591 & \\
\hline & & $\mathrm{PM}_{2.5}$ & 8.7391 & 0.4621 & \\
\hline \multirow{2}{*}{$12 / 13 / 2006$} & \multirow{2}{*}{058} & $\mathrm{PM}_{10}$ & 15.5158 & 0.5283 & \\
\hline & & $\mathrm{PM}_{2.5}$ & 5.8261 & 0.4434 & \\
\hline \multirow[t]{2}{*}{$12 / 19 / 2006$} & \multirow[t]{2}{*}{059} & $\mathrm{PM}_{10}$ & 0.5819 & 0.4274 & $\begin{array}{l}\text { V: Invalid (void) analysis result; F : Filter } \\
\text { damaged }\end{array}$ \\
\hline & & $\mathrm{PM}_{2.5}$ & 7.2409 & 0.4516 & \\
\hline \multirow{2}{*}{$12 / 25 / 2006$} & \multirow{2}{*}{060} & $\mathrm{PM}_{10}$ & 8.1429 & 0.4571 & \\
\hline & & $\mathrm{PM}_{2.5}$ & 6.7000 & 0.4483 & \\
\hline \multirow{2}{*}{$12 / 31 / 2006$} & \multirow{2}{*}{061} & $\mathrm{PM}_{10}$ & 7.8619 & 0.4556 & \\
\hline & & $\mathrm{PM}_{2.5}$ & 4.9938 & 0.4393 & \\
\hline \multirow{2}{*}{$1 / 6 / 2007$} & \multirow{2}{*}{063} & $\mathrm{PM}_{10}$ & 3.1588 & 0.4319 & \\
\hline & & $\mathrm{PM}_{2.5}$ & 1.8727 & 0.4294 & \\
\hline \multirow{2}{*}{$1 / 12 / 2007$} & \multirow{2}{*}{064} & $\mathrm{PM}_{10}$ & 5.2413 & 0.4403 & \\
\hline & & $\mathrm{PM}_{2.5}$ & 2.1640 & 0.4300 & \\
\hline \multirow{2}{*}{$1 / 18 / 2007$} & \multirow{2}{*}{065} & $\mathrm{PM}_{10}$ & 12.2296 & 0.4926 & \\
\hline & & $\mathrm{PM}_{2.5}$ & 7.8652 & 0.4558 & \\
\hline \multirow{2}{*}{$1 / 24 / 2007$} & \multirow{2}{*}{066} & $\mathrm{PM}_{10}$ & 6.1148 & 0.4448 & F : Filter damaged \\
\hline & & $\mathrm{PM}_{2.5}$ & 4.9521 & 0.4391 & \\
\hline \multirow{2}{*}{$1 / 30 / 2007$} & \multirow{2}{*}{067} & $\mathrm{PM}_{10}$ & 25.7273 & 0.6688 & \\
\hline & & $\mathrm{PM}_{2.5}$ & 7.4906 & 0.4533 & \\
\hline \multirow{2}{*}{$2 / 5 / 2007$} & \multirow{2}{*}{069} & $\mathrm{PM}_{10}$ & 18.8695 & 0.5701 & \\
\hline & & $\mathrm{PM}_{2.5}$ & 4.7857 & 0.4384 & \\
\hline \multirow{2}{*}{$2 / 11 / 2007$} & \multirow{2}{*}{070} & $\mathrm{PM}_{10}$ & 6.9052 & 0.4494 & F : Filter damaged \\
\hline & & $\mathrm{PM}_{2.5}$ & 4.8293 & 0.4387 & \\
\hline
\end{tabular}




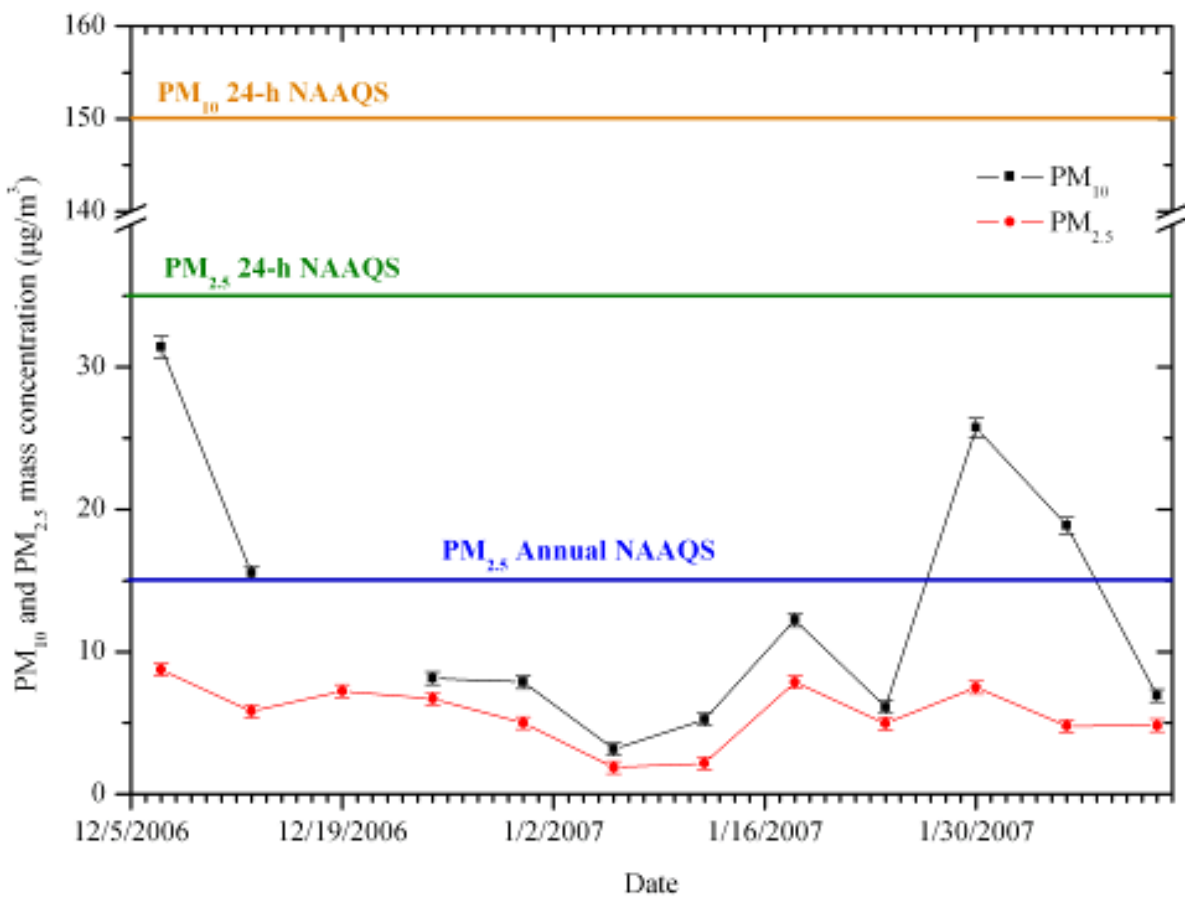

Figure 4. Time series of $\mathrm{PM}_{10}$ and $\mathrm{PM}_{2.5}$ mass concentrations ( \pm uncertainty) at Site \#5 (Caliente).

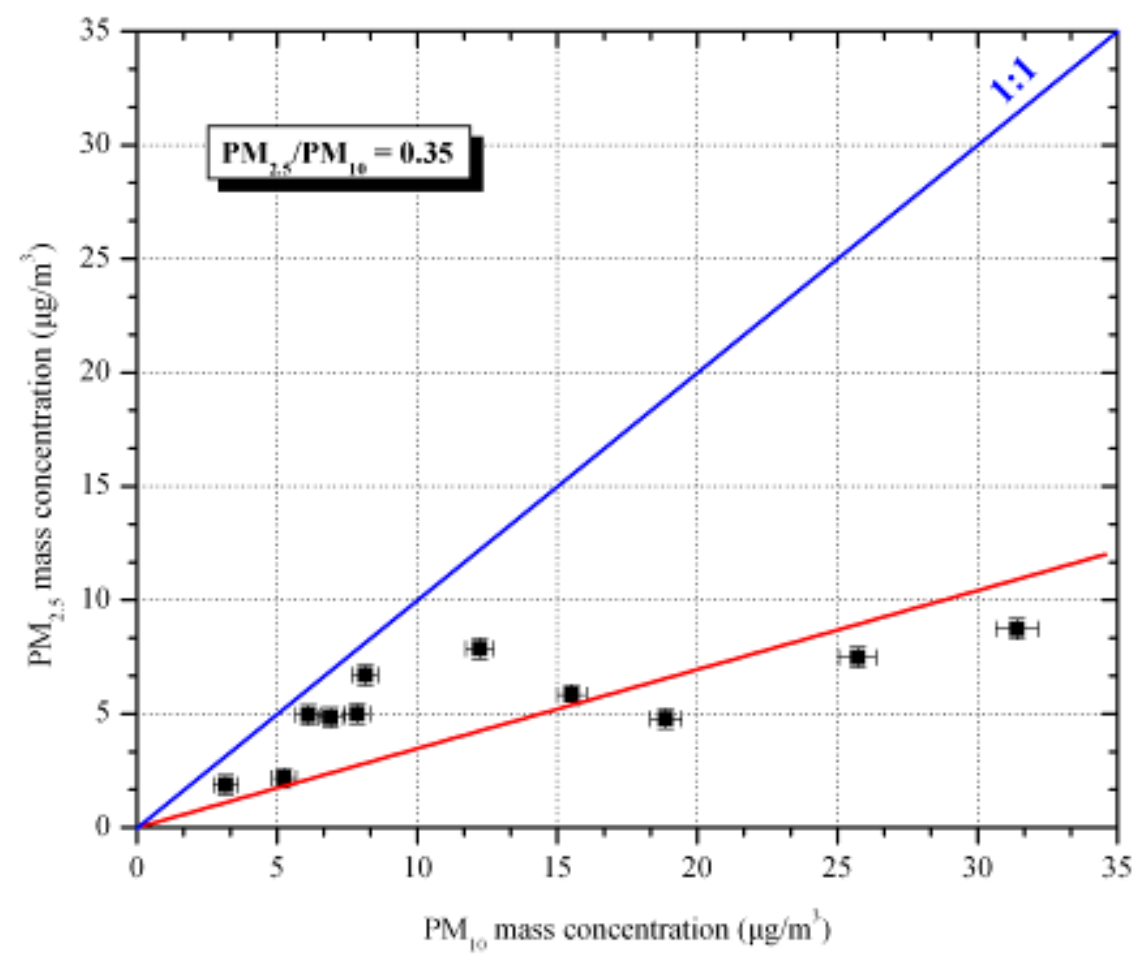

Figure 5. Relationship between mean ( \pm uncertainty) daily $\mathrm{PM}_{2.5}$ and $\mathrm{PM}_{10}$ at Caliente. 


\section{Chemical Analysis}

Table 3 shows the chemical content of $\mathrm{PM}_{10}$ and $\mathrm{PM}_{2.5}$ samples collected on 12/07/2006 and 1/30/2007. Chemical analysis included elements (from sodium to uranium) with X-ray fluorescence spectrometry (XRF), major anions (sulfate, nitrate, and chloride) by ion chromatography (IC), major cations (sodium, potassium, calcium and magnesium) by atomic absorption (AA), particulate ammonium by automated colorimetry (AC), and elemental, organic and carbonate carbon by thermal optical reflectance (TOR).

Table 3. Results of the chemical analysis for selected filters from Caliente. Chemical components with concentrations higher than twice the uncertainty are in bold, while those with concentrations lower than two times the uncertainty are in italics. Concentrations are in $\mu \mathrm{g} / \mathrm{m}^{3}$.

\begin{tabular}{|c|c|c|c|c|c|c|c|c|}
\hline \multirow{3}{*}{$\begin{array}{l}\text { DATE } \\
\text { SIZE }\end{array}$} & \multicolumn{4}{|c|}{$12 / 07 / 2006$} & \multicolumn{4}{|c|}{$1 / 30 / 2007$} \\
\hline & \multicolumn{2}{|c|}{$\mathrm{PM}_{10}$} & \multicolumn{2}{|c|}{$\mathrm{PM}_{2.5}$} & \multicolumn{2}{|c|}{$\mathrm{PM}_{10}$} & \multicolumn{2}{|c|}{$\mathrm{PM}_{2.5}$} \\
\hline & Conc. & Uncer. & Conc. & Uncer. & Conc. & Uncer. & Conc. & Uncer. \\
\hline Mass & 31.4132 & 0.7591 & 8.7391 & 0.4621 & 25.7273 & 0.6688 & 7.4906 & 0.4533 \\
\hline Chloride, $\mathrm{Cl}^{-}$ & 0.0649 & 0.0299 & 0.0377 & 0.0296 & 0.0654 & 0.0300 & 0.0272 & 0.0295 \\
\hline Nitrate, $\mathrm{NO}_{3}^{-}$ & 0.6246 & 0.0357 & 0.3485 & 0.0316 & 2.1798 & 0.0749 & 1.3137 & 0.0511 \\
\hline Sulfate, $\mathrm{SO}_{4}{ }^{2-}$ & 0.4529 & 0.031 & 0.3836 & 0.0306 & 0.694 & 0.0331 & 0.5923 & 0.0321 \\
\hline Ammonium, $\mathrm{NH}_{4}{ }^{+}$ & 0.1958 & 0.0303 & 0.1729 & 0.0302 & 0.5923 & 0.0363 & 0.5506 & 0.0355 \\
\hline Sodium, $\mathrm{Na}^{+}$ & 0.0583 & 0.0058 & 0.0236 & 0.0056 & 0.066 & 0.0058 & 0.0114 & 0.0056 \\
\hline Magnesium, $\mathrm{Mg}^{2+}$ & 0.0628 & 0.0021 & 0.0166 & 0.0013 & 0.053 & 0.0019 & 0.0076 & 0.0012 \\
\hline Potassium, $\mathrm{K}^{+}$ & 0.1136 & 0.0041 & 0.0687 & 0.0034 & 0.1241 & 0.0043 & 0.0928 & 0.0037 \\
\hline Calcium, $\mathrm{Ca}^{2+}$ & 1.4495 & 0.0385 & 0.2083 & 0.0161 & 1.108 & 0.031 & 0.0644 & 0.0153 \\
\hline $\mathrm{OC} 1$ & 0.1834 & 0.0741 & 0.3098 & 0.1219 & 0.1514 & 0.0623 & 0.1818 & 0.0735 \\
\hline $\mathrm{OC} 2$ & 1.0193 & 0.2399 & 1.1515 & 0.268 & 0.9319 & 0.2214 & 0.4215 & 0.116 \\
\hline OC3 & 1.5689 & 0.2722 & 1.2142 & 0.2356 & 2.0149 & 0.3217 & 0.8369 & 0.1997 \\
\hline OC4 & 0.7557 & 0.0945 & 0.8347 & 0.1013 & 1.1768 & 0.1322 & 1.3335 & 0.1468 \\
\hline Pyrolyzed OC-TT & 1.964 & 0.6697 & 1.0299 & 0.3526 & 1.48 & 0.5052 & 0.8801 & 0.3019 \\
\hline Pyrolyzed OC-Op & 1.3611 & 0.4844 & 0.5213 & 0.1886 & 0.7732 & 0.2768 & 0.7469 & 0.2676 \\
\hline Total OC & 4.8885 & 0.488 & 4.0315 & 0.4232 & 5.0482 & 0.5006 & 3.5206 & 0.3856 \\
\hline $\mathrm{EC} 1$ & 2.7782 & 0.6331 & 1.8956 & 0.4324 & 2.1127 & 0.4818 & 1.563 & 0.3569 \\
\hline $\mathrm{EC} 2$ & 0.3049 & 0.1128 & 0.3219 & 0.1186 & 0.2562 & 0.0966 & 0.1859 & 0.0741 \\
\hline EC3 & 0 & 0.0115 & 0 & 0.0115 & 0 & 0.0115 & 0 & 0.0115 \\
\hline Total EC & 1.7219 & 0.3328 & 1.6963 & 0.328 & 1.5957 & 0.3089 & 1.002 & 0.197 \\
\hline Total Carbon & 6.8832 & 0.6703 & 5.7405 & 0.5771 & 6.9086 & 0.6726 & 4.5227 & 0.4804 \\
\hline $\begin{array}{l}\text { Carbonate Carbon } \\
\left(\mathrm{CO}_{3}{ }^{2-}\right)\end{array}$ & 0.2728 & 0.2284 & 0.0127 & 0.215 & 0.2647 & 0.2281 & 0 & 0.2149 \\
\hline Sodium, $\mathrm{Na}$ & 0.097 & 0.0815 & 0.046 & 0.081 & 0.186 & 0.0831 & 0 & 0.0799 \\
\hline Magnesium, Mg & 0.2623 & 0.0444 & 0.0619 & 0.0433 & 0.1892 & 0.044 & 0.0184 & 0.0431 \\
\hline Aluminum, Al & 1.0275 & 0.0239 & 0.1991 & 0.0089 & 0.7208 & 0.0178 & 0.0547 & 0.0075 \\
\hline Silicon, Si & 2.9496 & 0.0639 & 0.5135 & 0.0144 & 2.0417 & 0.0449 & 0.1576 & 0.0091 \\
\hline Phosphorous, P & 0.0026 & 0.0029 & 0.0063 & 0.003 & 0.008 & 0.003 & 0.0113 & 0.003 \\
\hline Sulfur, S & 0.1471 & 0.0127 & 0.129 & 0.0126 & 0.2349 & 0.0134 & 0.2061 & 0.0132 \\
\hline Chlorine, $\mathrm{Cl}$ & 0.0084 & 0.0016 & 0 & 0.0016 & 0.0041 & 0.0016 & 0.0023 & 0.0016 \\
\hline Potassium, K & 0.6200 & 0.0127 & 0.1446 & 0.0034 & 0.4994 & 0.0103 & 0.1328 & 0.0031 \\
\hline Calcium, Ca & 1.3095 & 0.0265 & 0.1976 & 0.0045 & 1.1071 & 0.0224 & 0.0811 & 0.0025 \\
\hline Scandium, Sc & 0 & 0.0058 & 0 & 0.0058 & 0.0022 & 0.0058 & 0 & 0.0058 \\
\hline Titanium, Ti & 0.0638 & 0.0017 & 0.0106 & 0.0011 & 0.0531 & 0.0016 & 0.0041 & 0.0011 \\
\hline
\end{tabular}


Table 3. Results of the chemical analysis for selected filters from Caliente. Chemical components with concentrations higher than twice the uncertainty are in bold, while those with concentrations lower than two times the uncertainty are in italics. Concentrations are in $\mu \mathrm{g} / \mathrm{m}^{3}$ (continued).

\begin{tabular}{|c|c|c|c|c|c|c|c|c|}
\hline \multirow{3}{*}{$\begin{array}{l}\text { DATE } \\
\text { SIZE }\end{array}$} & \multicolumn{4}{|c|}{$12 / 07 / 2006$} & \multicolumn{4}{|c|}{$1 / 30 / 2007$} \\
\hline & \multicolumn{2}{|c|}{$\mathrm{PM}_{10}$} & \multicolumn{2}{|c|}{$\mathrm{PM}_{2.5}$} & \multicolumn{2}{|c|}{$\mathrm{PM}_{10}$} & \multicolumn{2}{|c|}{$\mathrm{PM}_{2.5}$} \\
\hline & Conc. & Uncer. & Conc. & Uncer. & Conc. & Uncer. & Conc. & Uncer. \\
\hline Vanadium, V & 0.0004 & 0.0001 & 0 & 0.0001 & 0.0003 & 0.0001 & 0 & 0.0001 \\
\hline Chromium, $\mathrm{Cr}$ & 0 & 0.001 & 0 & 0.001 & 0 & 0.001 & 0 & 0.001 \\
\hline Manganese, Mn & 0.0181 & 0.0022 & 0.0019 & 0.0021 & 0.0132 & 0.0022 & 0.0015 & 0.0021 \\
\hline Iron, $\mathrm{Fe}$ & 0.7639 & 0.0158 & 0.1096 & 0.0038 & 0.5803 & 0.0122 & 0.0372 & 0.0031 \\
\hline Cobalt, Co & 0 & 0.0001 & 0 & 0.0001 & 0 & 0.0001 & 0 & 0.0001 \\
\hline Nickel, Ni & 0 & 0.0006 & 0 & 0.0006 & 0 & 0.0006 & 0 & 0.0006 \\
\hline Copper, $\mathrm{Cu}$ & 0.0014 & 0.0009 & 0 & 0.0009 & 0.0027 & 0.0009 & 0 & 0.0009 \\
\hline Zinc, Zn & 0.0076 & 0.0009 & 0.0022 & 0.0009 & 0.0105 & 0.0009 & 0.005 & 0.0009 \\
\hline Gallium, Ga & 0 & 0.0031 & 0.0013 & 0.0031 & 0.0015 & 0.0031 & 0 & 0.0031 \\
\hline Arsenic, As & 0 & 0.0001 & 0 & 0.0001 & 0 & 0.0001 & 0 & 0.0001 \\
\hline Selenium, Se & 0 & 0.0020 & 0 & 0.0021 & 0.0009 & 0.0021 & 0.0024 & 0.0021 \\
\hline Bromine, $\mathrm{Br}$ & 0.0006 & 0.0015 & 0.0011 & 0.0015 & 0.0048 & 0.0015 & 0.0059 & 0.0015 \\
\hline Rubidium, Rh & 0.0017 & 0.0011 & 0 & 0.0011 & 0.0017 & 0.0011 & 0 & 0.0011 \\
\hline Strontium, Sr & 0.0088 & 0.0020 & 0.0008 & 0.0002 & 0.0084 & 0.002 & 0.0003 & 0.0020 \\
\hline Yttrium, Y & 0.0004 & 0.0015 & 0.0006 & 0.0015 & 0.0005 & 0.0015 & 0 & 0.0015 \\
\hline Zirconium, Zr & 0.0004 & 0.0034 & 0.0015 & 0.0034 & 0.0037 & 0.0035 & 0 & 0.0034 \\
\hline Niobium, $\mathrm{Nb}$ & 0.0010 & 0.0026 & 0 & 0.0026 & 0 & 0.0026 & 0 & 0.0026 \\
\hline Molybdenum, Mo & 0 & 0.0023 & 0.0006 & 0.0024 & 0.0011 & 0.0024 & 0 & 0.0024 \\
\hline Palladium, Pd & 0.0015 & 0.0045 & 0 & 0.0045 & 0 & 0.0045 & 0.0009 & 0.0045 \\
\hline Silver, Ag & 0.0007 & 0.0041 & 0 & 0.0041 & 0.0012 & 0.0041 & 0 & 0.0041 \\
\hline Cadmium, Cd & 0 & 0.0051 & 0 & 0.0052 & 0 & 0.0052 & 0 & 0.0052 \\
\hline Indium, In & 0 & 0.0030 & 0.0001 & 0.003 & 0 & 0.003 & 0.0006 & 0.003 \\
\hline Tin, Sn & 0 & 0.0038 & 0 & 0.0039 & 0 & 0.0039 & 0 & 0.0039 \\
\hline Antimony, Sb & 0.0007 & 0.0072 & 0.0018 & 0.0073 & 0 & 0.0072 & 0 & 0.0073 \\
\hline Cesium, Cs & 0 & 0.0012 & 0 & 0.0012 & 0 & 0.0012 & 0 & 0.0012 \\
\hline Barium, Ba & 0 & 0.0006 & 0 & 0.0006 & 0 & 0.0006 & 0 & 0.0006 \\
\hline Lanthanum, La & 0 & 0.0009 & 0 & 0.0009 & 0 & 0.0009 & 0.0006 & 0.0009 \\
\hline Cerium, $\mathrm{Ce}$ & 0 & 0.0013 & 0 & 0.0013 & 0 & 0.0013 & 0 & 0.0013 \\
\hline Samarium, Sa & 0 & 0.0018 & 0.0002 & 0.0018 & 0 & 0.0018 & 0 & 0.0018 \\
\hline Europium, Eu & 0.0016 & 0.0064 & 0.0003 & 0.0064 & 0 & 0.0064 & 0 & 0.0064 \\
\hline Terbium, Tb & 0 & 0.0024 & 0.0006 & 0.0024 & 0 & 0.0024 & 0 & 0.0024 \\
\hline Hafnium, Hf & 0 & 0.0139 & 0 & 0.0139 & 0 & 0.014 & 0 & 0.0139 \\
\hline Tantalum, Ta & 0 & 0.0116 & 0 & 0.0117 & 0.0051 & 0.0117 & 0.0051 & 0.0117 \\
\hline Tungsten, W & 0 & 0.0167 & 0 & 0.0168 & 0.0107 & 0.0168 & 0.0103 & 0.0168 \\
\hline Iridium, Ir & 0 & 0.0036 & 0 & 0.0036 & 0 & 0.0036 & 0 & 0.0036 \\
\hline Gold, Au & 0.0029 & 0.0078 & 0 & 0.0078 & 0.0001 & 0.0078 & 0 & 0.0078 \\
\hline Mercury, Hg & 0 & 0.0023 & 0 & 0.0024 & 0 & 0.0024 & 0 & 0.0024 \\
\hline Thallium, Th & 0 & 0.0024 & 0 & 0.0025 & 0 & 0.0025 & 0 & 0.0025 \\
\hline Lead, $\mathrm{Pb}$ & 0 & 0.0025 & 0 & 0.0025 & 0.0002 & 0.0025 & 0 & 0.0025 \\
\hline Uranium, U & 0 & 0.0041 & 0.0026 & 0.0041 & 0 & 0.0041 & 0.0027 & 0.0041 \\
\hline
\end{tabular}

$\mathrm{OC}=$ organic carbon

$\mathrm{EC}=$ elemental carbon

$\mathrm{OP}=$ optical pyrolysis

$\mathrm{TT}=$ transmittance 
With respect to the chemical composition of $\mathrm{PM}_{10}$ and $\mathrm{PM}_{2.5}$, the following patterns are observed:

- $\quad$ Sulfur (S) was mostly in the form of sulfate $\left(\mathrm{SO}_{4}{ }^{2-}\right)$ with sulfate-to-sulfur ratio of 2.87 to 3.03. Sulfate and ammonium were almost entirely associated with fine particles, while about 50 percent of nitrate (55 to $60 \%$ ) was measured in $\mathrm{PM}_{2.5}$. Ammonium-tosulfate molar ratios varied from 2.31 to 4.96, suggesting that sulfate aerosols were mostly in the form of ammonium sulfate, $\left(\mathrm{NH}_{4}\right)_{2} \mathrm{SO}_{4}$ (Malm et al., 2002). Nitrates appeared to be partially neutralized by ammonium in the fine particle mode, while coarse particles nitrates may be the product of the reactions of nitric acid with soil dust elements such as $\mathrm{Ca}^{2+}, \mathrm{Mg}^{2+}, \mathrm{Na}^{+}$, and $\mathrm{K}^{+}$(Lefer and Talbot, 2001).

- Carbonaceous aerosol was predominantly in fine particles. For $\mathrm{PM}_{2.5}$, organic carbon (OC) concentrations accounted for 66 percent of particle mass. The EC/OC ratio varied from 0.28 to 0.42 , which was indicative of fossil fuel combustion emissions.

- Soluble potassium $\left(\mathrm{K}^{+}\right)$accounted for 18 to 25 percent of total potassium in $\mathrm{PM}_{10}$ and for 48 to 70 percent of total potassium in $\mathrm{PM}_{2.5}$. Soluble potassium is a tracer of biomass burning, which suggested the significant impact of emissions from local wood burning and/or regional fire (prescribed or wildfire) events and possible salts in the desert soil. This was further supported by the estimates of nonsoil potassium $\mathrm{K}_{\text {non- }}$ soil $\left(\mathrm{K}_{\text {total }}-(0.26 \mathrm{x}[\mathrm{Al}])\right)$ that were comparable to measured water-soluble $\mathrm{K}^{+}$for $\mathrm{PM}_{2.5}$. Water soluble $\mathrm{K}^{+}$is also present as salts in soils.

- Ratios of $\mathrm{Al} / \mathrm{Si}(0.35$ to 0.39$) \mathrm{K} / \mathrm{Fe}\left(0.81\right.$ for $\left.\mathrm{PM}_{10}\right), \mathrm{Al} / \mathrm{Ca}(0.65$ to 1.01$)$ were comparable to those determined for samples collected at the Interagency Monitoring of Protected Visibility Environments (IMPROVE) sites in western United States (Al/Si: 0.31 to $0.43, \mathrm{~K} / \mathrm{Fe}: 0.67$ to $0.78, \mathrm{Al} / \mathrm{Ca}: 1.4$ to 1.7 ) when soil dust was the major component of particulate matter (Kavouras et al., 2005).

The IMPROVE mass calculation was applied to reconstruct aerosol mass into five major types: sulfate, nitrate, organic, light-absorbing carbon, and soil. For this scheme, sulfate and nitrate are assumed to be in the forms of ammonium sulfate $\left[\left(\mathrm{NH}_{4}\right)_{2} \mathrm{SO}_{4}\right]$ and ammonium nitrate $\left[\mathrm{NH}_{4} \mathrm{NO}_{3}\right]$, respectively (Malm et al., 2004). Organic mass concentration $[\mathrm{OMC}]$ was estimated as $[\mathrm{OMC}]=1.4 \mathrm{x}[\mathrm{OC}]$, where $[\mathrm{OC}]$ is the organic carbon concentration. The 1.4 factor was used to estimate for elements not measured (mainly hydrogen and oxygen) in organic compounds (White and Roberts, 1977). Soil mass concentration [SOIL] was estimated as the sum of the elements present in the soil as oxides $\left(\mathrm{Al}_{2} \mathrm{O}_{3}, \mathrm{SiO}_{2}, \mathrm{CaO}, \mathrm{K}_{2} \mathrm{O}, \mathrm{FeO}, \mathrm{Fe}_{2} \mathrm{O}_{3}\right.$, and $\left.\mathrm{TiO}_{2}\right)$ as follows:

$[\mathrm{SOIL}]=2.2 \times[\mathrm{Al}]+2.49[\mathrm{Si}]+1.63 \times[\mathrm{Ca}]+2.42 \times[\mathrm{Fe}]+1.94 \times[\mathrm{Ti}]$. Therefore, the reconstructed aerosol mass was estimated as follows:

$[$ Aerosol Mass $]=(128 / 96) \times\left[\mathrm{SO}_{4}\right]+(80 / 62) \times\left[\mathrm{NO}_{3}\right]+\mathrm{EC}+[\mathrm{OMC}]+[\mathrm{SOIL}]$

Figure 6 shows the concentrations of ammonium sulfate, ammonium nitrate, organic carbon mass, elemental carbon, and soil for $\mathrm{PM}_{10}$ and $\mathrm{PM}_{2.5}$ collected on 12/07/2006 and 1/30/2007 in Caliente. Considering the positive bias for organic carbon measurements:

- Reconstructed particle mass accounted for 75 to 87 percent of measured $\mathrm{PM}_{10}$ mass and for 122 percent of $\mathrm{PM}_{2.5}$ mass. The difference between estimated and measured aerosol mass for $\mathrm{PM}_{10}$ may be attributed to particle-bound water, as lower ambient 
temperatures during winter favored condensation. Carbonate $\left(\mathrm{CO}_{3}{ }^{2-}\right)$ (not shown in Figure 6) accounted for $1.3 \mu \mathrm{g} / \mathrm{m}^{3}$ of $\mathrm{PM}_{10}$ for both samples. The neutralization of coarse nitrate by calcium may also be a contributing factor, since calcium is mostly present as $\mathrm{Ca}^{2+}$.

- Carbonaceous aerosol (OMC and EC) appeared to account for 27 to 33 percent of $\mathrm{PM}_{10}$ and 79 to 84 percent of $\mathrm{PM}_{2.5}$.

- Soil represented 39 to 44 percent of $\mathrm{PM}_{10}$ and about 10 to 27 percent of $\mathrm{PM}_{2.5}$ mass, while sulfate contributed between 2 and 4 percent on $\mathrm{PM}_{10}$ and 6 to 11 percent on $\mathrm{PM}_{2.5}$ (Figure 6).

- The differences of $\mathrm{PM}_{10}$ and $\mathrm{PM}_{2.5}$ fractions are due to higher concentration of soil elements in the coarse fraction (particles with diameter between 2.5 and $10 \mu \mathrm{m}$ ).

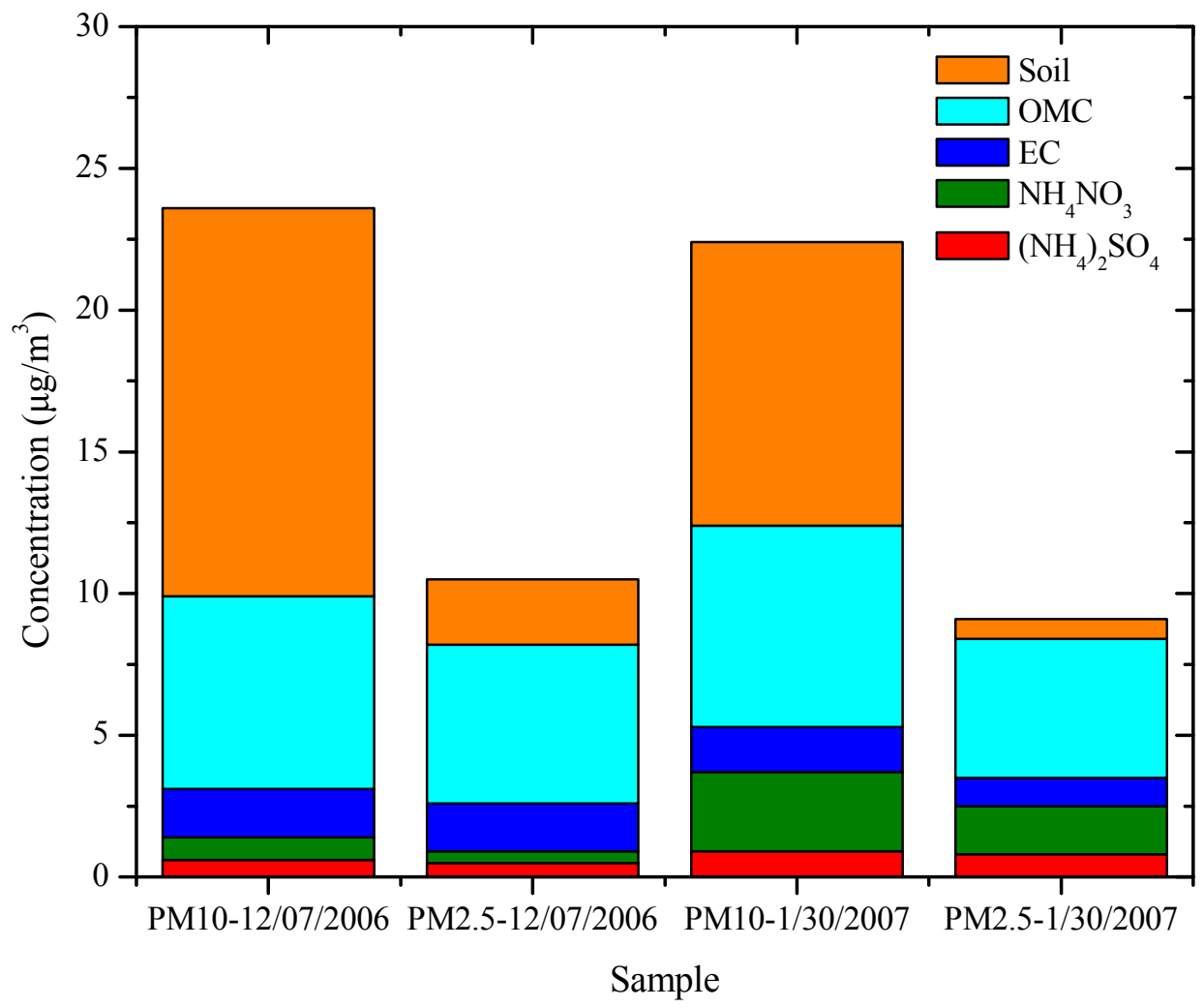

Figure 6. Reconstructed mass for $\mathrm{PM}_{10}$ and $\mathrm{PM}_{2.5}$ based on chemical composition.

\section{Aerosol Monitoring}

\section{Monitor Description and Procedures}

The TEOM Series 1400 Ambient Particulate Monitor from Thermo Scientific and the DUSTTRAK ${ }^{\mathrm{TM}}$ Aerosol Monitor from TSI were used to continuously measure $\mathrm{PM}_{10}$ and $\mathrm{PM}_{2.5}$ mass concentrations (Figure 7). The TEOM Series 1400 monitors the ambient particulate mass concentration of $\mathrm{PM}_{10}$ (EPA certification EQPM-1090-079) (or $\mathrm{PM}_{2.5}$ ) in real time by direct measurement of particulate mass collected on a filter attached to an 
oscillating inertial mass transducer. The mass transducer in the sensor unit has a tapered ceramic tube (element) that is fixed at the downstream end and a Teflon-coated glass fiber filter on the free end. The oscillating frequency of the tube changes proportionally as ambient air is drawn through the filter and the particulate loading thereon increases. The flow-rate through the filter sample is set at a nominal $3.0 \mathrm{l} / \mathrm{min}$. A bypass (auxiliary) flow provides an additional $13.67 \mathrm{l} / \mathrm{min}$ for a total flow-rate of $16.67 \mathrm{l} / \mathrm{min}$. An internal datalogger stores mass values, time, and some meteorological data. To eliminate bias caused by humidity, the filter is heated to $50^{\circ} \mathrm{C}$. Operation, calibration and maintenance of the TEOM unit is described in DRI SOP 4-111.2 "RUPPRECHT \& PATASHNICK (R\&P), SERIES 1400A TAPERED ELEMENT OSCILLATING MICROBALANCE (TEOM)." Flow calibration and leak tests were performed on the day of installation (December 5, 2006). Data were downloaded during site visits. Regular checks of time, filter loading, by-pass filter, and flow rates were accomplished during site visits.

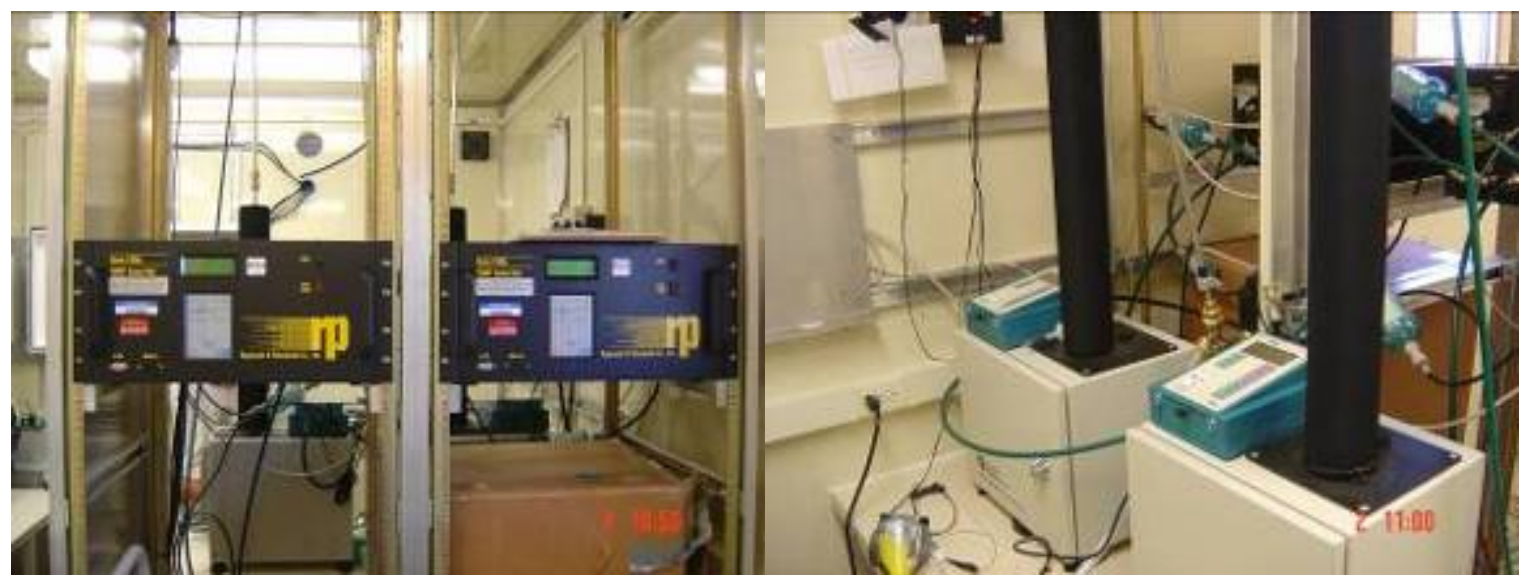

Figure 7. Left photograph: The front panels of $\mathrm{PM}_{10}$ (right on the left photograph) and $\mathrm{PM}_{2.5}$ (left on the left photograph) of TEOM. Right photograph: The DustTrak monitors (green) resting on top of the two TEOM measuring units.

The DUSTTRAK ${ }^{\mathrm{TM}}$ Aerosol Monitor is a portable, battery operated laser photometer providing measurements of particle mass, based on light scattering. Atmospheric aerosol passes through a size selective inlet (either $\mathrm{PM}_{10}$ or $\mathrm{PM}_{2.5}$ ) and is directed to an optics chamber at a flow rate of $1.7 \mathrm{l} / \mathrm{min}$. The light source is a laser diode that emits light at a wavelength of $780 \mathrm{~nm}$. Sampled aerosol is drawn into the sensing chamber where it is illuminated with a narrow beam of laser light. Light scattered by aerosol particles is collected by a set of lenses and focused onto the photodetector. The detector signal is proportional to the amount of scattered light, which is proportional to the mass concentration of the aerosol. Voltage is read by the processor and multiplied by an internal calibration constant to yield mass concentration. The calibration constant is pre-set by the manufacturer for scattering characteristics of the respirable mass of ISO 12103-1, Al-test dust. Local variations in aerosol particle size distribution and composition relative to this standard may result in differences in the actual response factor of the instrument. The operation, calibration, and maintenance of DUSTTRAK are described in DRI SOP 1.211-2 "TSI INCORPORATED MODEL 8520 DustTrak AEROSOL MONITOR FOR THE YUCCA MOUNTAIN AIR QUALITY PROGRAM." 
Both $\mathrm{PM}_{10}$ and $\mathrm{PM}_{2.5}$ DUSTTRAK inlets were attached on a wide "Y" connector, which was connected to one leg of a second "Y" (Figure 8). A funnel with a suction fan was connected to the other leg of the second "Y" to achieve fast exchange of ambient air into the sampling line. Flow calibration and zero-test were performed on the day of installation and subsequent site visits. Deviations in flow were predominantly due to failure of the pump diaphragm. In those cases, the instrument was replaced. Deviations of the zero check were corrected by performing zero calibration according to the manufacturer's operational instruction manual.

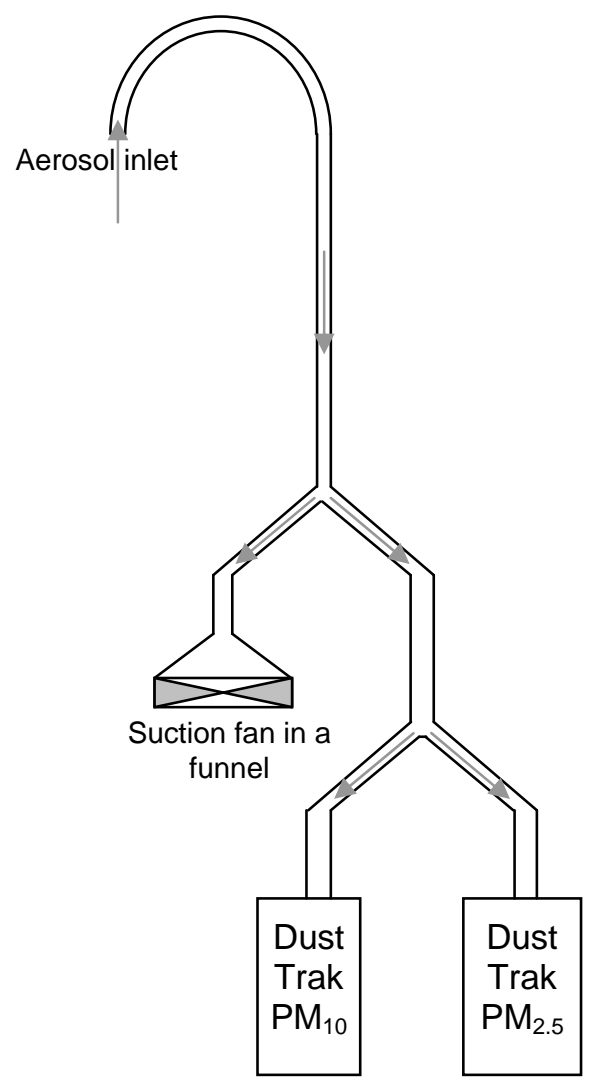

Figure 8. Schematic drawing of the sampling inlet for DUSTTRAK (not to scale).

\section{Continuous Measurements of $\mathrm{PM}_{10} \underline{\text { and } \mathrm{PM}_{2.5}}$}

Trends and correlations of particle mass are examined using hourly TEOM data integrated for 24 hours (from 0:00. to 23:59). Statistics of 24-h particle mass are presented in Table 4.

Table 4. Statistics for 24-h $\mathrm{PM}_{10}$ and $\mathrm{PM}_{2.5}$ TEOM mass concentrations.

\begin{tabular}{rrrrrr}
\hline & Mean & Median & Minimum & Maximum & Std. Deviation \\
\hline $\mathrm{PM}_{10}$ & 20.5 & 14.9 & 5.0 & 69.6 & 14.8 \\
$\mathrm{PM}_{2.5}$ & 4.9 & 4.6 & 1.4 & 13.8 & 2.3 \\
\hline
\end{tabular}


Daily $\mathrm{PM}_{10}$ levels ranged from 5.0 to $69.6 \mu \mathrm{g} / \mathrm{m}^{3}$, with a mean of $20.5(\sigma=14.8)$ $\mu \mathrm{g} / \mathrm{m}^{3}$, while $\mathrm{PM}_{2.5}$ concentrations varied from 1.4 to $13.8 \mu \mathrm{g} / \mathrm{m}^{3}$, with a mean of $4.9(\sigma=1.4)$ $\mu \mathrm{g} / \mathrm{m}^{3} . \mathrm{PM}_{10}$ and $\mathrm{PM}_{2.5}$ show similar temporal trends. The highest $\mathrm{PM}_{10}$ concentrations were measured at the beginning and end of the monitoring campaign (Figure 9). A consistent relationship between PM fractions was observed during the monitoring period, with fine particles being accounted for 20 percent of $\mathrm{PM}_{10}\left(\mathrm{PM}_{2.5} / \mathrm{PM}_{10}\right.$ ratio of 0.20$)$ (Figure 10). The lowest $\mathrm{PM}_{10}$ concentrations were measured on Mondays and Sundays (Days \#1 and \#7) (Figure 11).

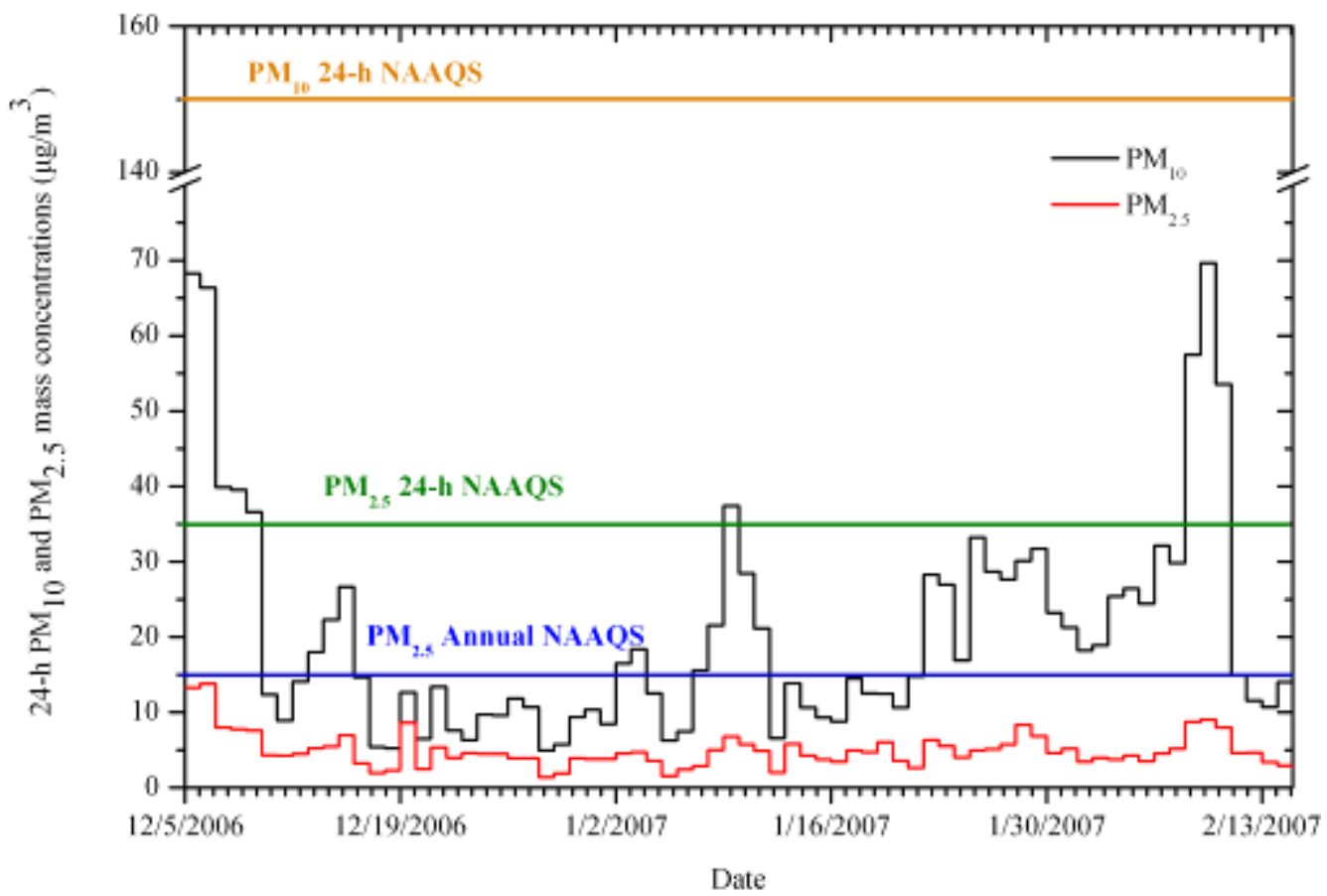

Figure 9. Mean 24-h $\mathrm{PM}_{10}$ and $\mathrm{PM}_{2.5}$ mass concentrations measured by TEOM at Site \#5 (Caliente). 


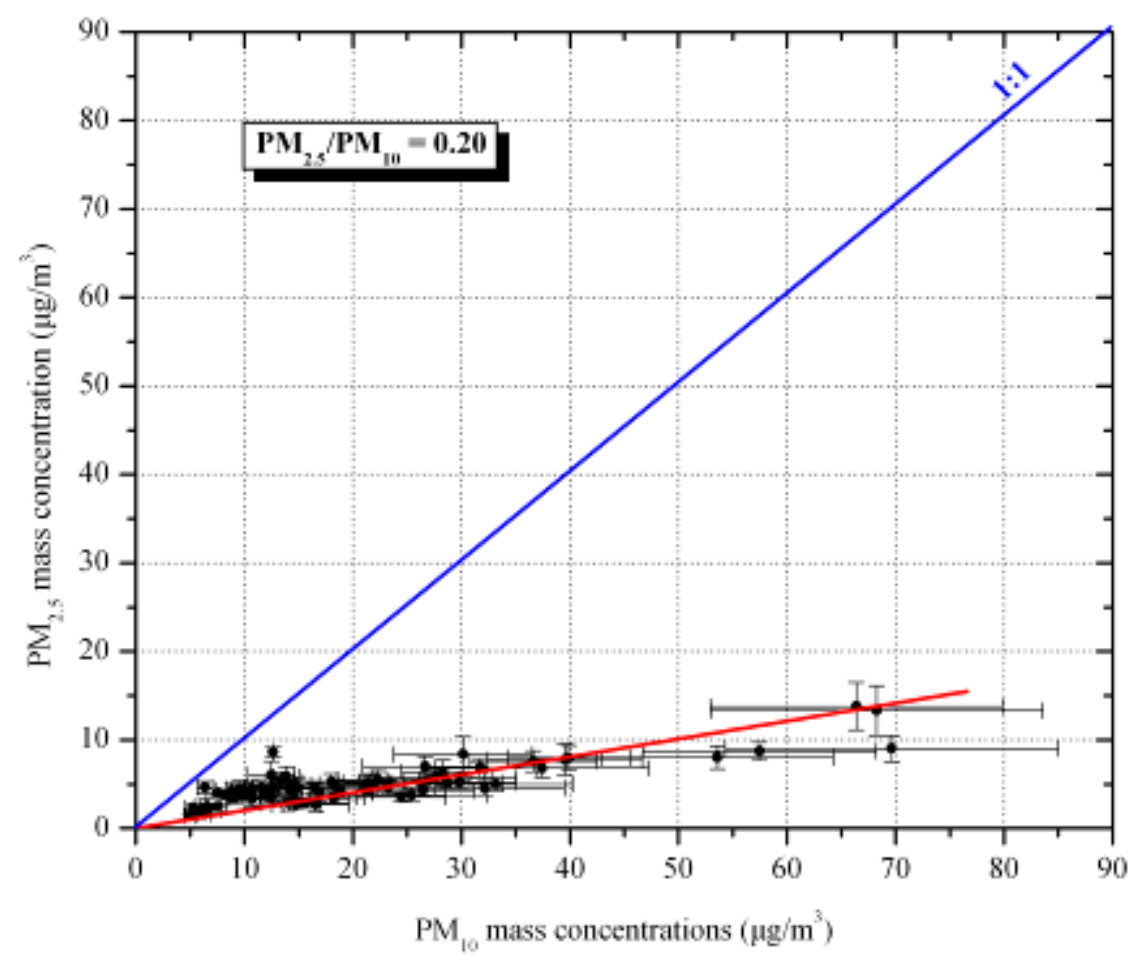

Figure 10. $\mathrm{PM}_{2.5} / \mathrm{PM}_{10}$ mass ratios measured by TEOM at Site \#5 (Caliente). Error bars represent the standard error of the mean.

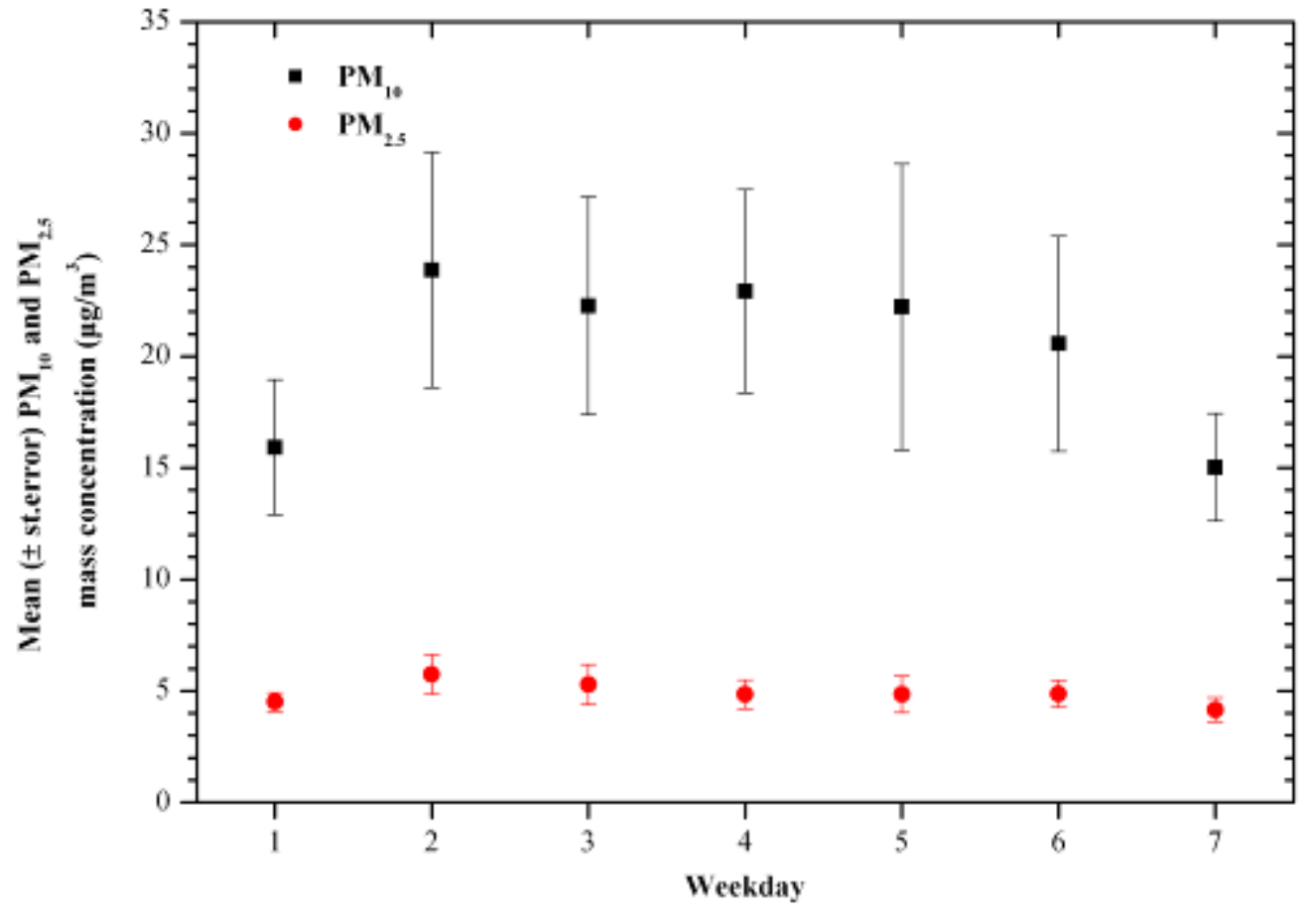

Figure 11. Variation of mean ( \pm st.error) $\mathrm{PM}_{10}$ and $\mathrm{PM}_{2.5}\left(\mu \mathrm{g} / \mathrm{m}^{3}\right)$ in weekdays and weekends at Site \#5 (Caliente) $($ Monday $=1$, Tuesday $=2$, Wednesday $=3$, Thursday $=4$, Friday $=5$, Saturday $=6$, Sunday $=7)$. 
Variations of daily $\mathrm{PM}_{10}$ and $\mathrm{PM}_{2.5}$ measured with DUSTTRAK and TEOM are presented in Figure 12 and Figure 13. The temporal patterns (increase or decrease simultaneously) measured by DUSTTRAK and TEOM were comparable for both $\mathrm{PM}_{10}$ and $\mathrm{PM}_{2.5}$. Daily trends of particle mass concentrations measured by DUSTTRAK and TEOM were comparable for $\mathrm{PM}_{10}$ mass. The correlations between DUSTTRAK and TEOM were moderate to high $(\mathrm{R}=0.65$ to 0.79$)$. A slope of 0.55788 and an intercept of $-3.89448 \mu \mathrm{g} / \mathrm{m}^{3}$ (Figure 14) were computed for $\mathrm{PM}_{10}$. This was indicative of the weakness of the lightscattering technique to monitor dust particles that represented 80 percent of $\mathrm{PM}_{10}$ mass in Caliente. As for $\mathrm{PM}_{2.5}$, the slope between TEOM and DUSTTRAK $\mathrm{PM}_{2.5}$ was 2.66232, with a rather low intercept of $1.07191 \mu \mathrm{g} / \mathrm{m}^{3}$.

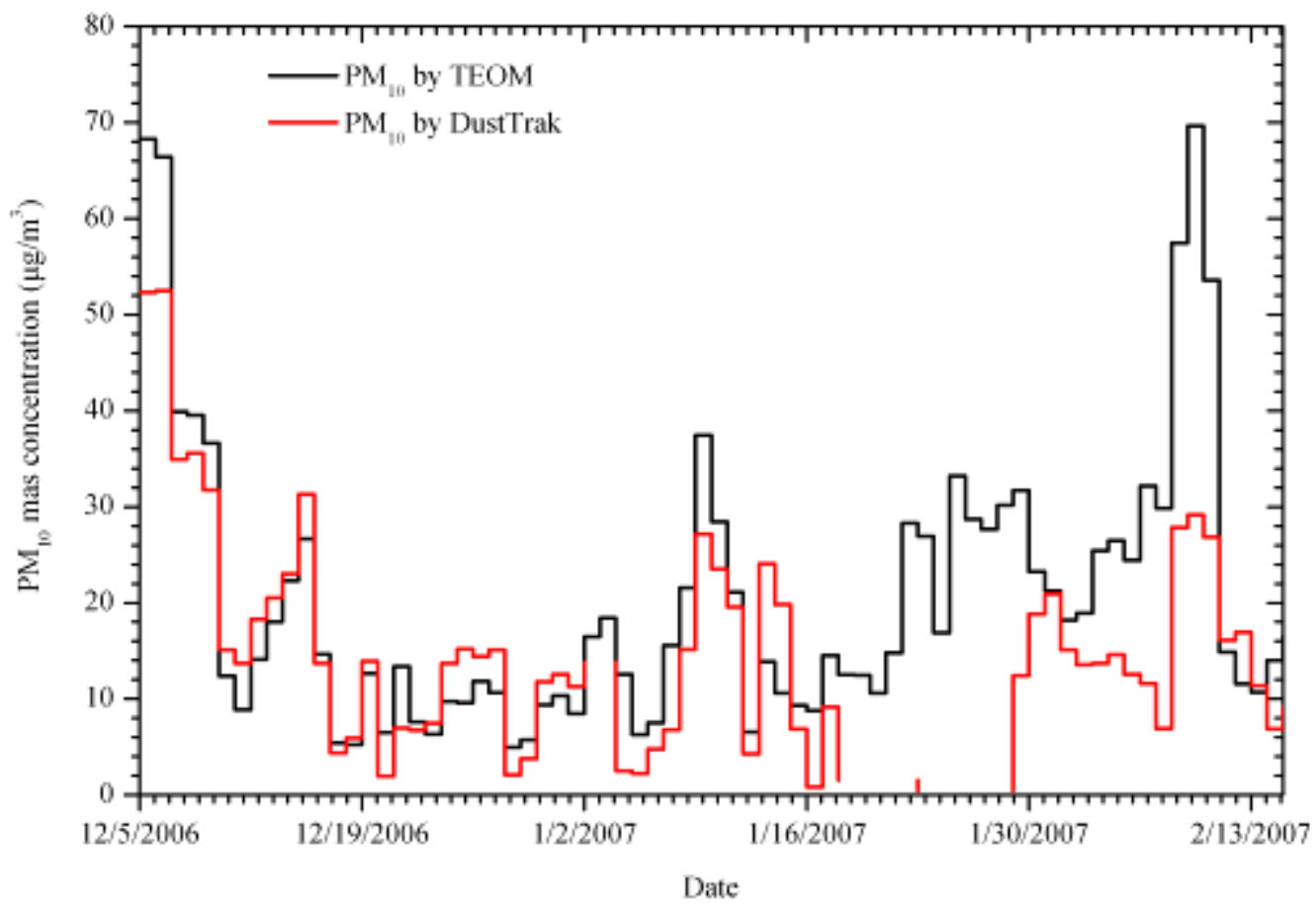

Figure 12. $\mathrm{PM}_{10}$ mass $\left(\mu \mathrm{g} / \mathrm{m}^{3}\right)$ measured with DUSTTRAK and TEOM at Site \#5 (Caliente). 


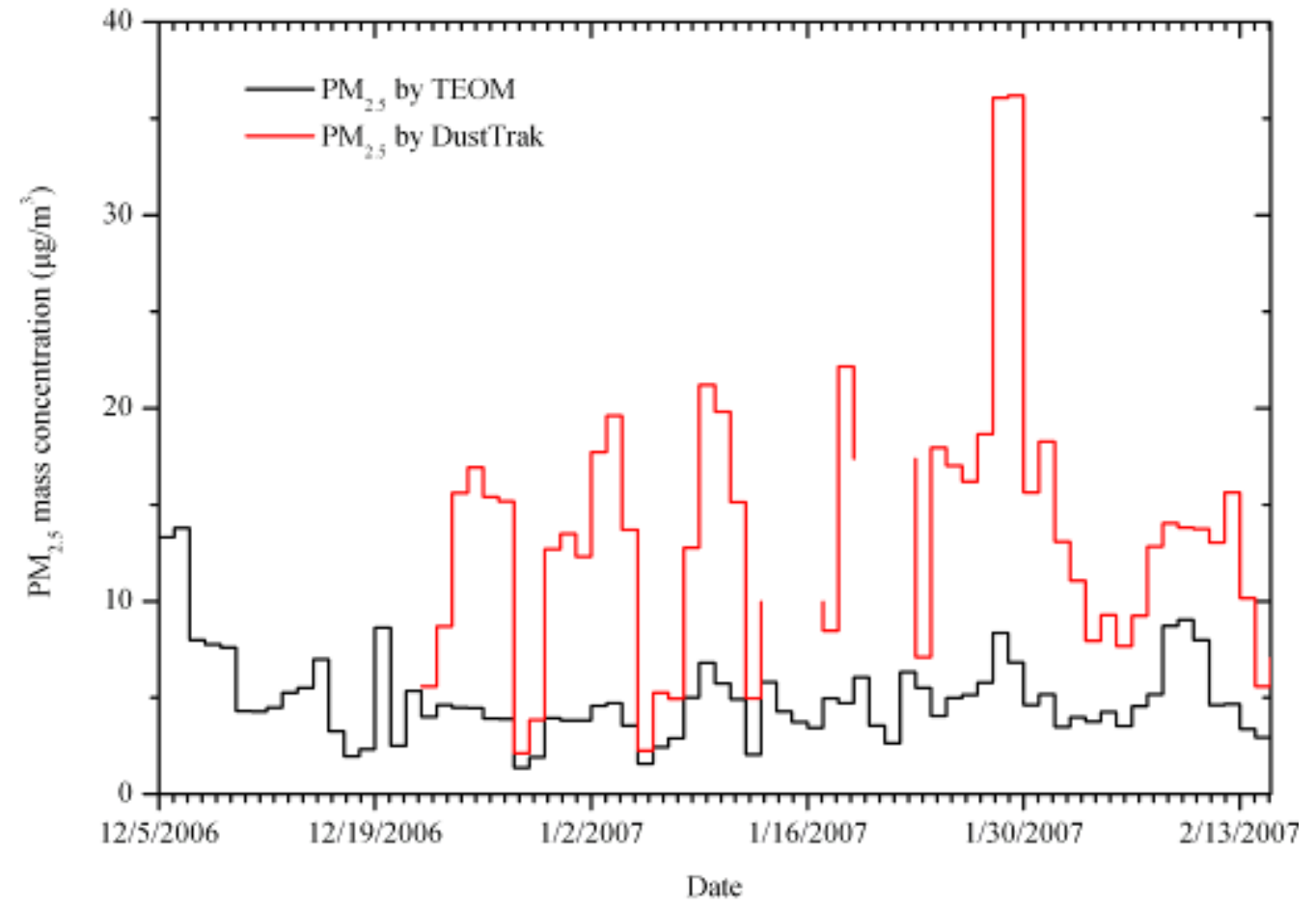

Figure 13. $\mathrm{PM}_{2.5}$ mass $\left(\mu \mathrm{g} / \mathrm{m}^{3}\right)$ measured with DUSTTRAK and TEOM at Site \#5 (Caliente).

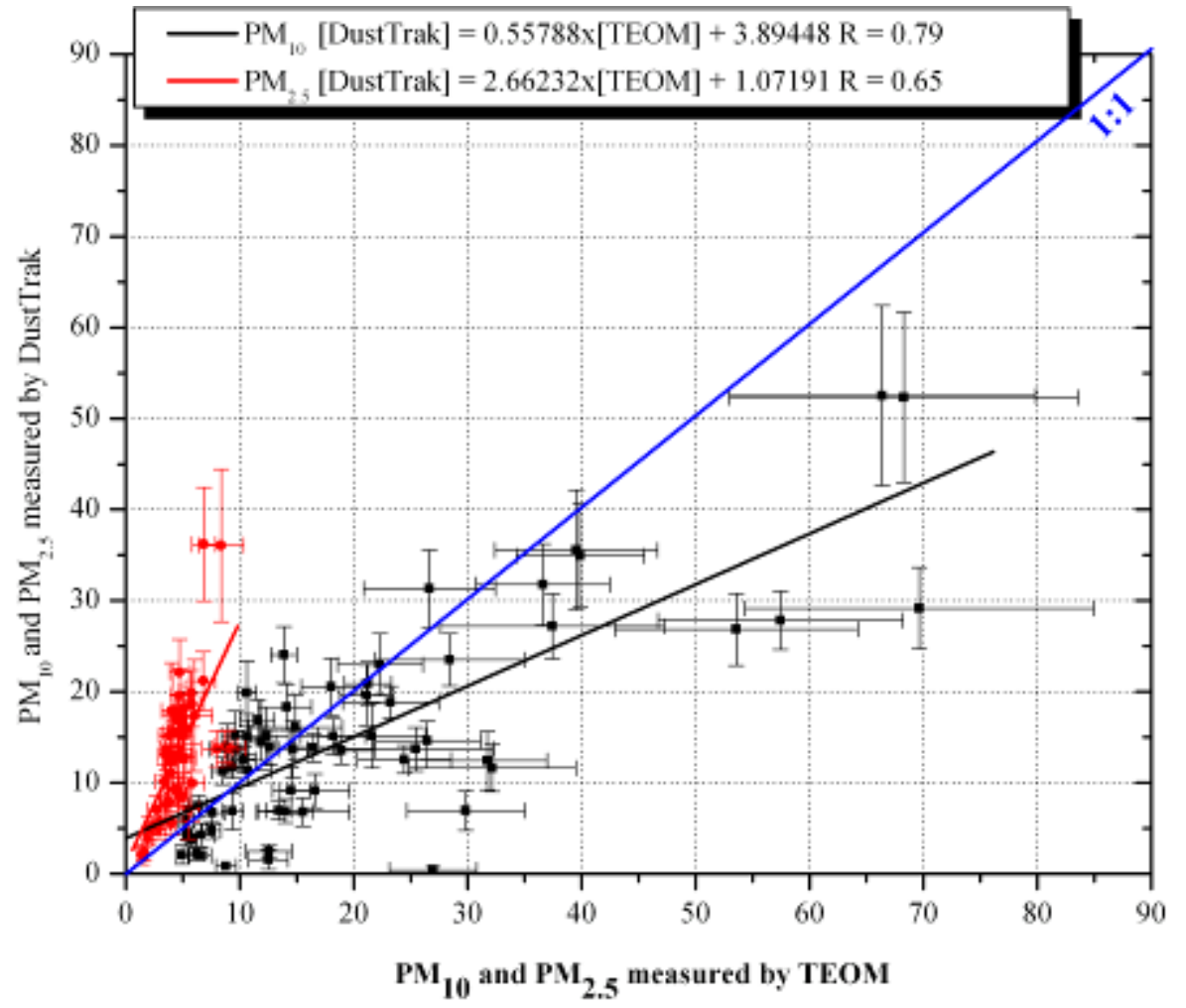

Figure 14. Comparison of 24-h $\mathrm{PM}_{10}$ and $\mathrm{PM}_{2.5}$ mass concentrations measured by TEOM and DUSTTRAK. Error bars represent the standard error of the mean. 


\section{Comparison of Filter to Continuous Results}

Figures 15 and 16 show the relationships between $\mathrm{PM}_{10}$ and $\mathrm{PM}_{2.5}$ measured by TEOM/DUSTTRAK and filter-based methods. The temporal correlations between $\mathrm{PM}_{10}$ and $\mathrm{PM}_{2.5}$ measurements by TEOM and filter methods were good, with correlation coefficients from 0.79 to 0.99 . Poor correlations were computed for $\mathrm{PM}_{10}$ and $\mathrm{PM}_{2.5}$ measurements by DustTrak and filter methods ( 0.47 to 0.49 ). The slope between TEOM/DUSTTRAK and filter-based $\mathrm{PM}_{10}$ measurements were 0.96858 for TEOM and 0.01588 for DUSTTRAK, while high intercepts are computed. The slopes for $\mathrm{PM}_{2.5}$ measured by TEOM and DUSTTRAK were 0.6597 and 0.31513 , respectively, with insignificant intercepts.

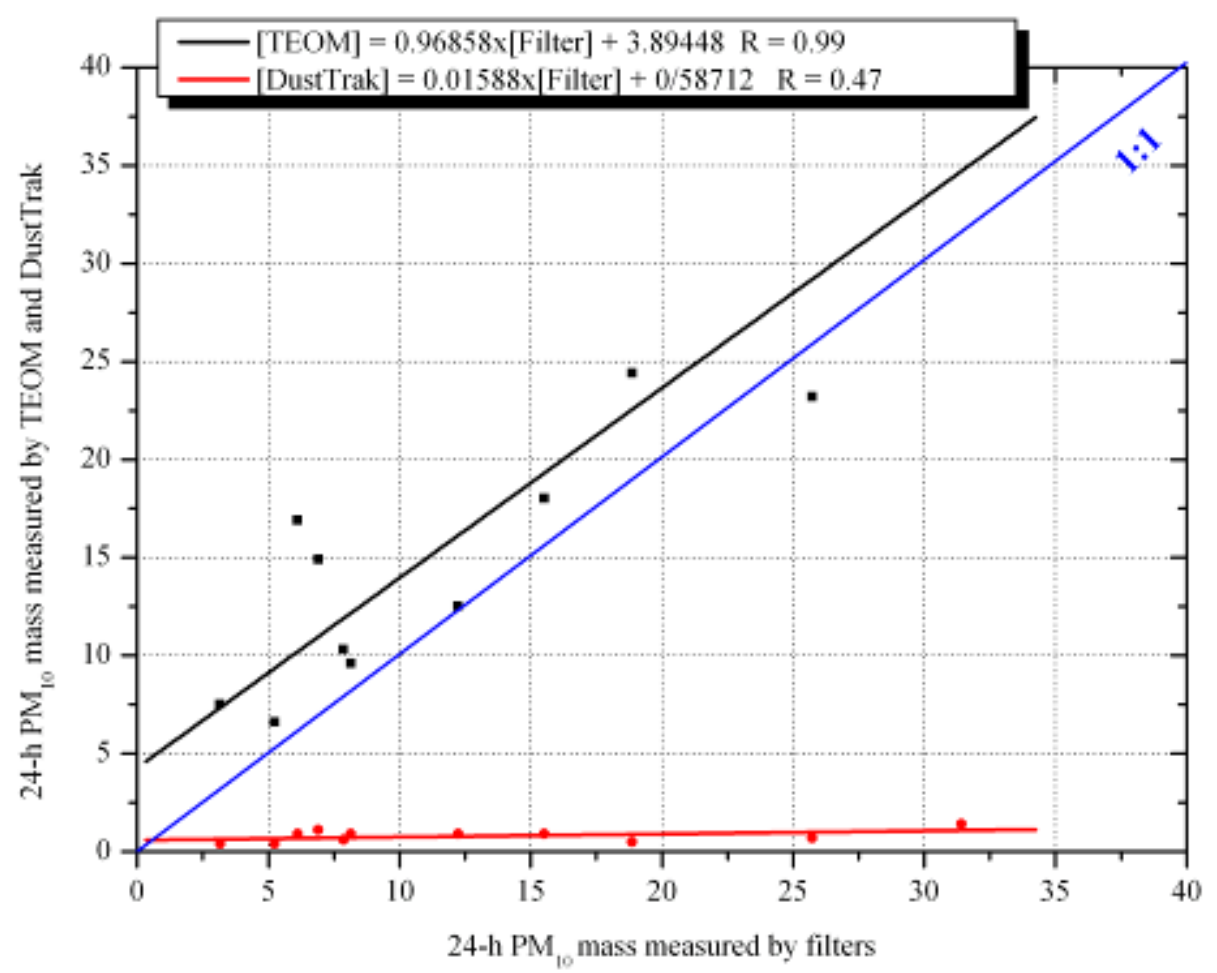

Figure 15. Relationships between $\mathrm{PM}_{10}$ concentrations $\left(\mu \mathrm{g} / \mathrm{m}^{3}\right)$ measured by TEOM, DUSTTRAK, and filter-based methods. 


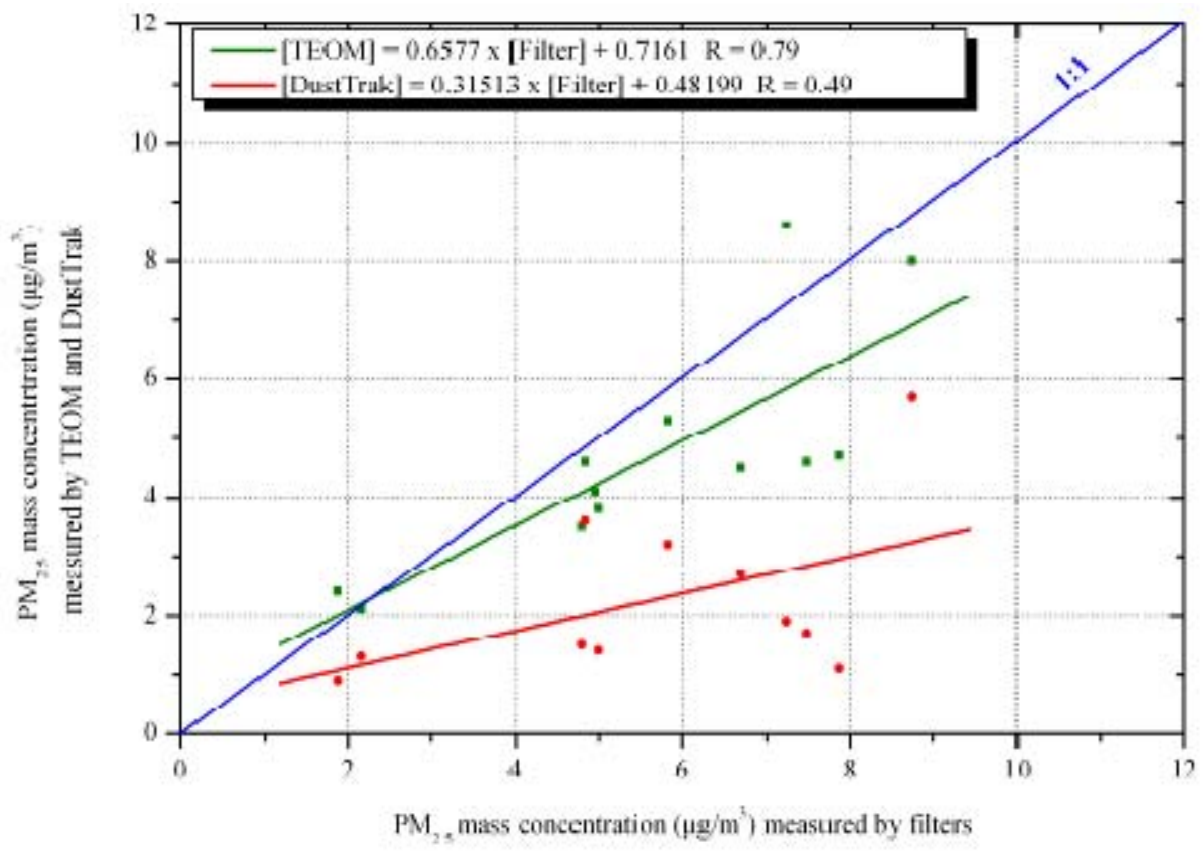

Figure 16. Relationships between $\mathrm{PM}_{2.5}$ concentrations $\left(\mu \mathrm{g} / \mathrm{m}^{3}\right)$ measured by TEOM, DUSTTRAK, and filter-based methods.

\section{METEOROLOGY}

Variations of hourly data for each meteorological parameter are presented in Figure 17 through Figure 21. Descriptive statistics of hourly data also are presented in Table 5. Solar radiation progressively increased up to $58.7 \mathrm{watts} / \mathrm{m}^{2}$ (Figure 17). Ambient temperature varied from -9.2 to $64.5^{\circ} \mathrm{F}$ with a mean temperature of $31.3^{\circ} \mathrm{F}$ for the monitoring period (Table 5; Figure 18). Relative humidity varied from 12 to 99.2 percent. Ten precipitation events were recorded with a total of $0.6 \mathrm{~mm}$ (Figure 19). Snow covered most of the region for several weeks in January and February.

Table 5. Descriptive statistics of 1-hour meteorological data.

\begin{tabular}{lrccc}
\hline & Mean & Minimum & Maximum & Sum \\
\hline Solar radiation (watts $\left./ \mathrm{m}^{2}\right)$ & 8.4 & 0.0 & 58.7 & \\
Wind speed $(\mathrm{miles} / \mathrm{h})$ & 1.7 & 0.0 & 13.8 & \\
Temperature $\left({ }^{\circ} \mathrm{F}\right)$ & 31.3 & -9.2 & 64.5 & \\
Relative humidity (\%) & 62.6 & 12.0 & 99.2 & \\
Precipitation $(\mathrm{mm})$ & & & & 0.6 \\
\hline
\end{tabular}




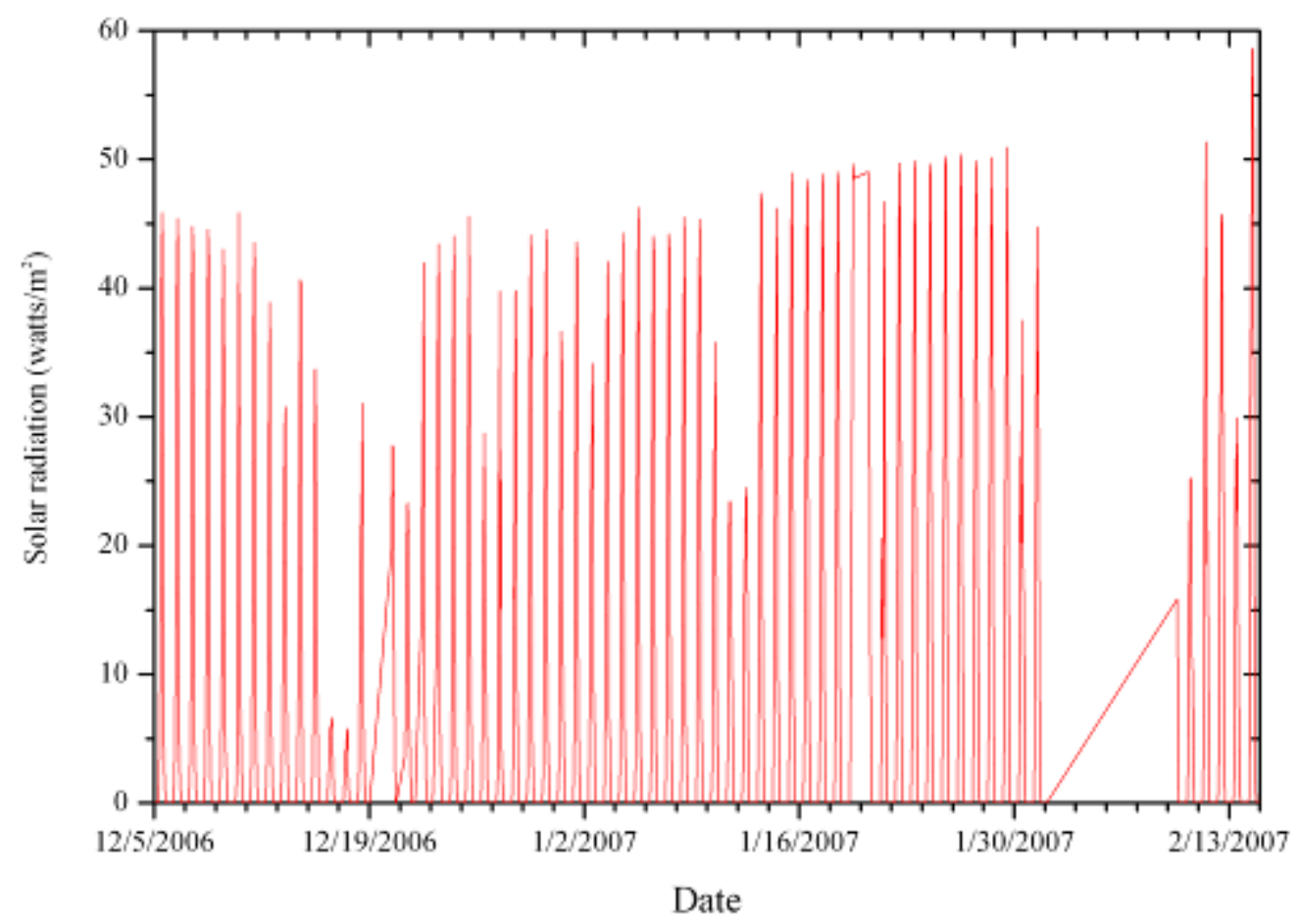

Figure 17. Solar radiation (in watts $/ \mathrm{m}^{2}$ ) at Site \#5 (Caliente).

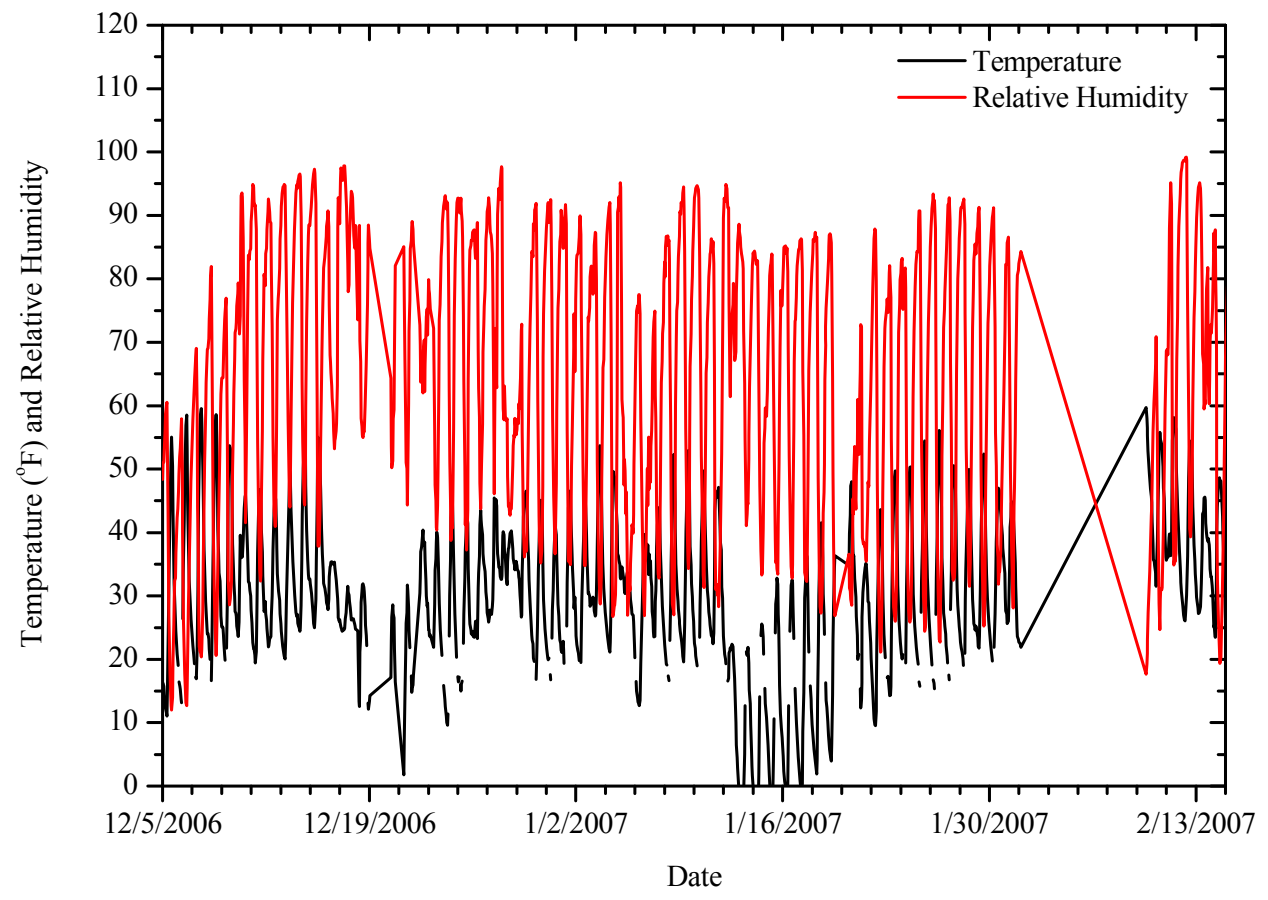

Figure 18. Temperature (in $\left.{ }^{\circ} \mathrm{F}\right)$ and relative humidity at Site \#5 (Caliente). 


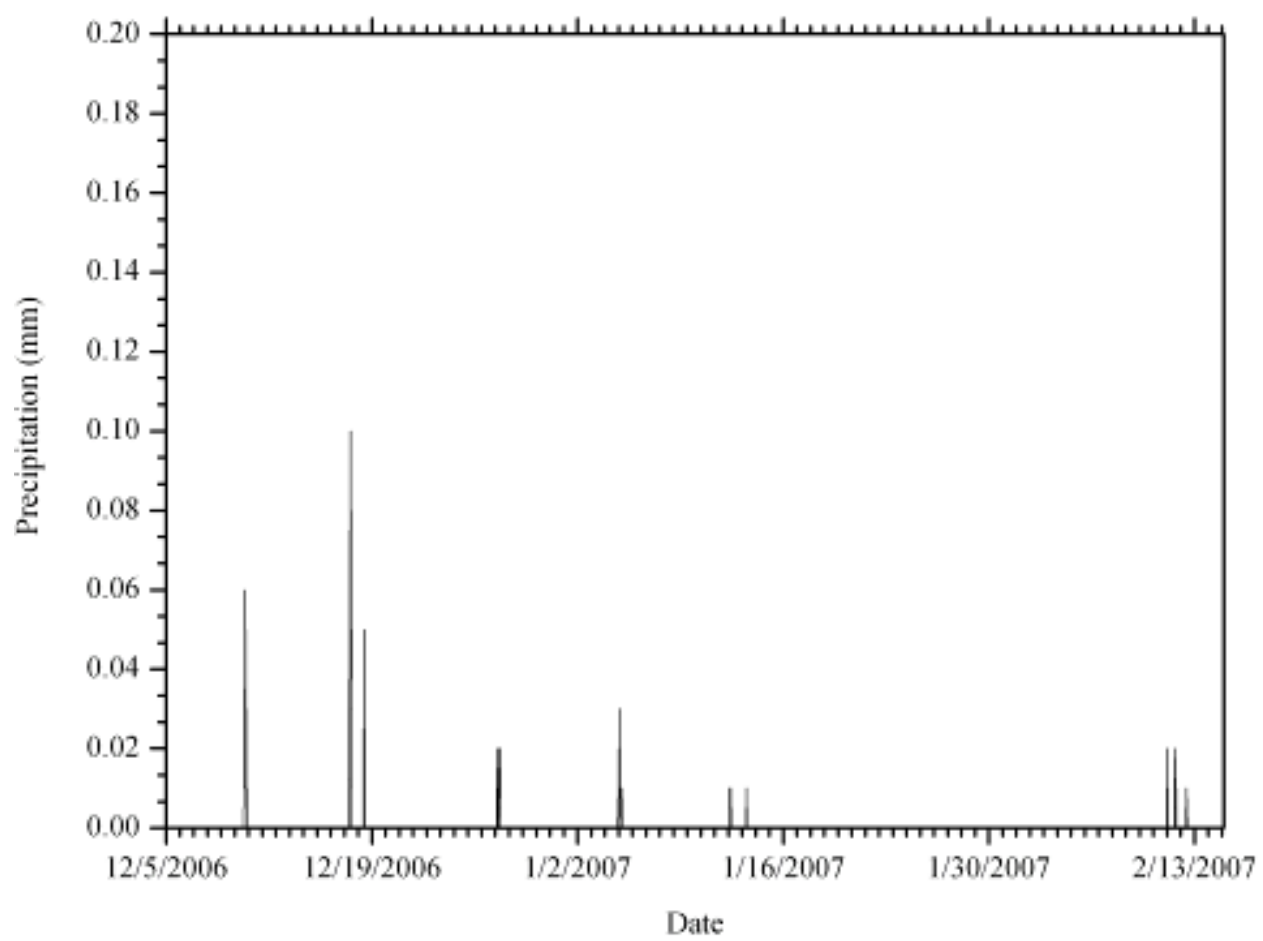

Figure 19. Precipitation (in $\mathrm{mm}$ ) and relative humidity at Site \#5 (Caliente).

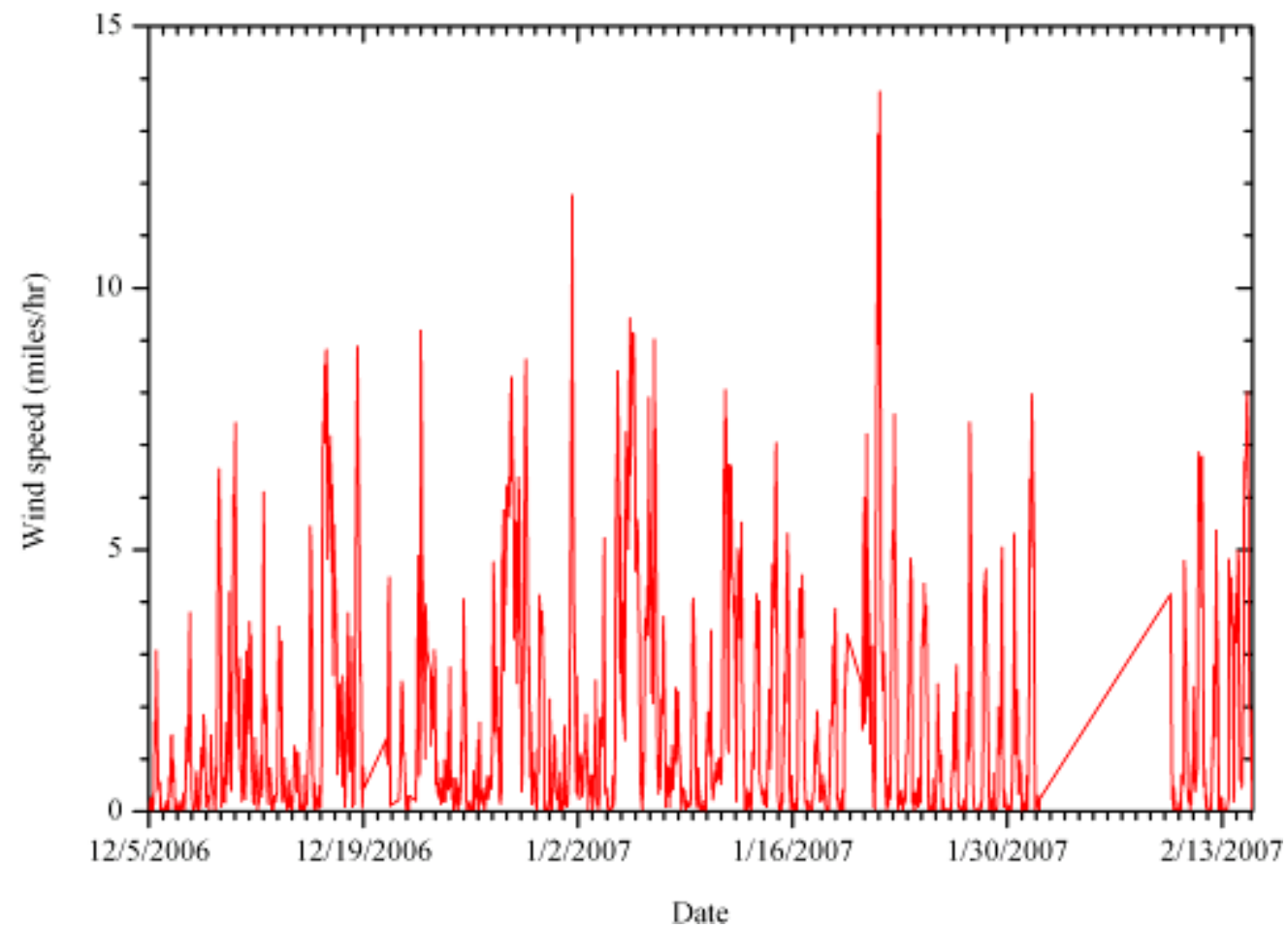

Figure 20. Wind speed (in miles/hr) at Site \#5 (Caliente). 


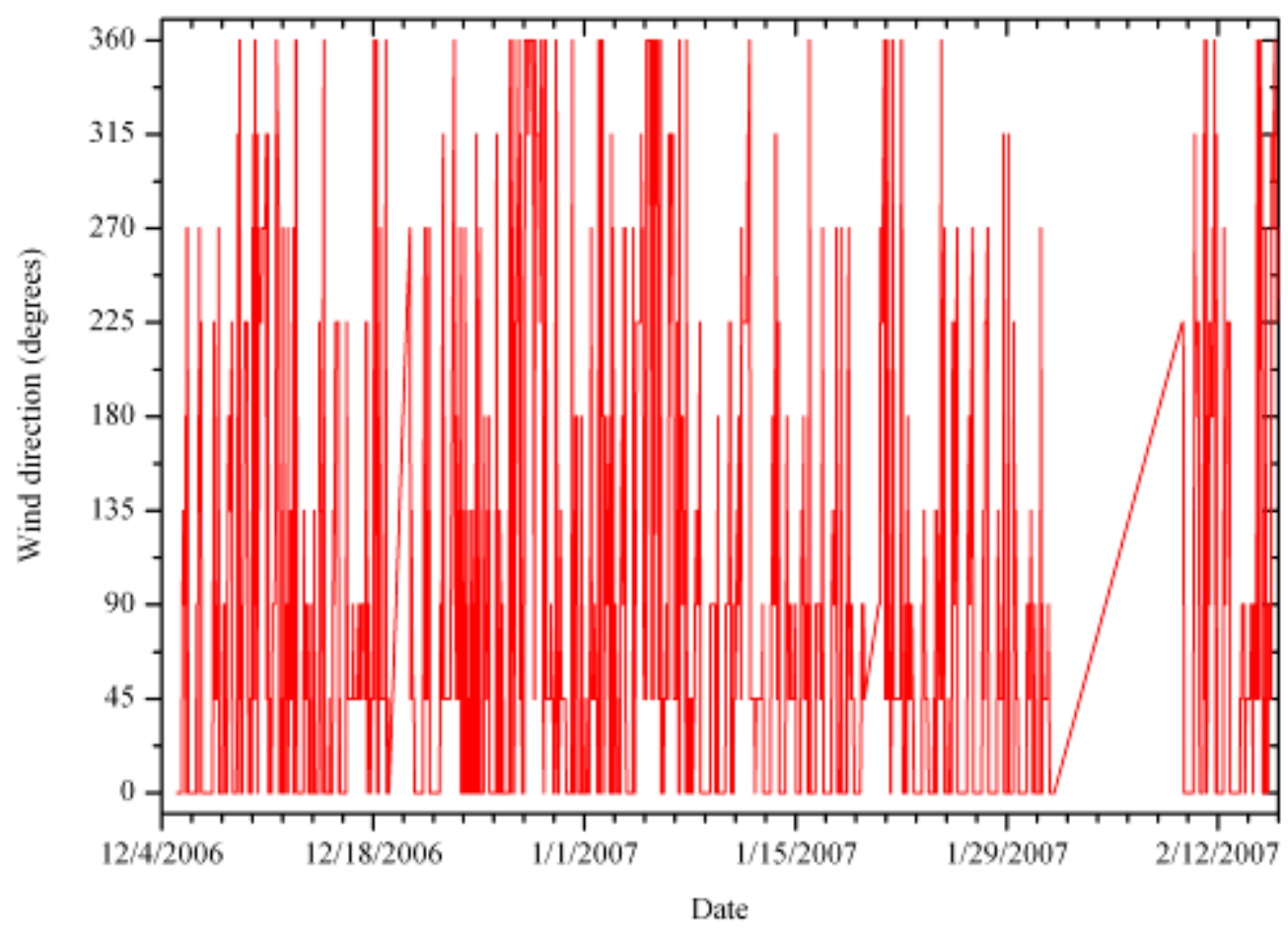

Figure 21. Wind direction at Site \#5 (Caliente).

Wind conditions for the monitoring period were described as very light winds from the northeast/east in the range of 1 to 9 miles/hour (Figure 20 and Figure 21). The classification of wind conditions was retrieved from the Federal Meteorological Handbook (Table 6). The mean wind speed for each direction bin ( 8 bins) is presented in Figure 22.

Table 6. Wind condition classifications.

\begin{tabular}{|c|c|}
\hline Miles/hour & Specification \\
\hline$<1$ & Calm; smoke rises vertically. \\
\hline 1 to 5 & $\begin{array}{l}\text { Direction of wind shown by smoke drift not by wind vanes. Wind felt on face; leaves } \\
\text { rustle; vanes moved by wind. }\end{array}$ \\
\hline 5 to 9 & Leaves and small twigs in constant motion; wind extends light flag. \\
\hline 9 to 14 & Raises dust, loose paper; small branches moved. \\
\hline 14 to 23 & $\begin{array}{l}\text { Small trees in leaf begin to sway; crested wavelets form on inland waters. Large branches } \\
\text { in motion; whistling heard in overhead wires; umbrellas used with difficulty. }\end{array}$ \\
\hline 23 to 35 & $\begin{array}{l}\text { Whole trees in motion; inconvenience felt walking against wind. Breaks twigs off trees; } \\
\text { impedes progress. }\end{array}$ \\
\hline $\begin{array}{l}35 \text { to } 48 \\
>48\end{array}$ & $\begin{array}{l}\text { Slight structural damage occurs. Trees uprooted; considerable damage occurs. } \\
\text { Widespread damage. }\end{array}$ \\
\hline
\end{tabular}

(retrieved from Federal Meteorological Handbook; Chapter 5. Wind;

http://www.nws.noaa.gov/oso/oso1/oso12/fmh1/fmh1ch5.htm\#chp5link) 


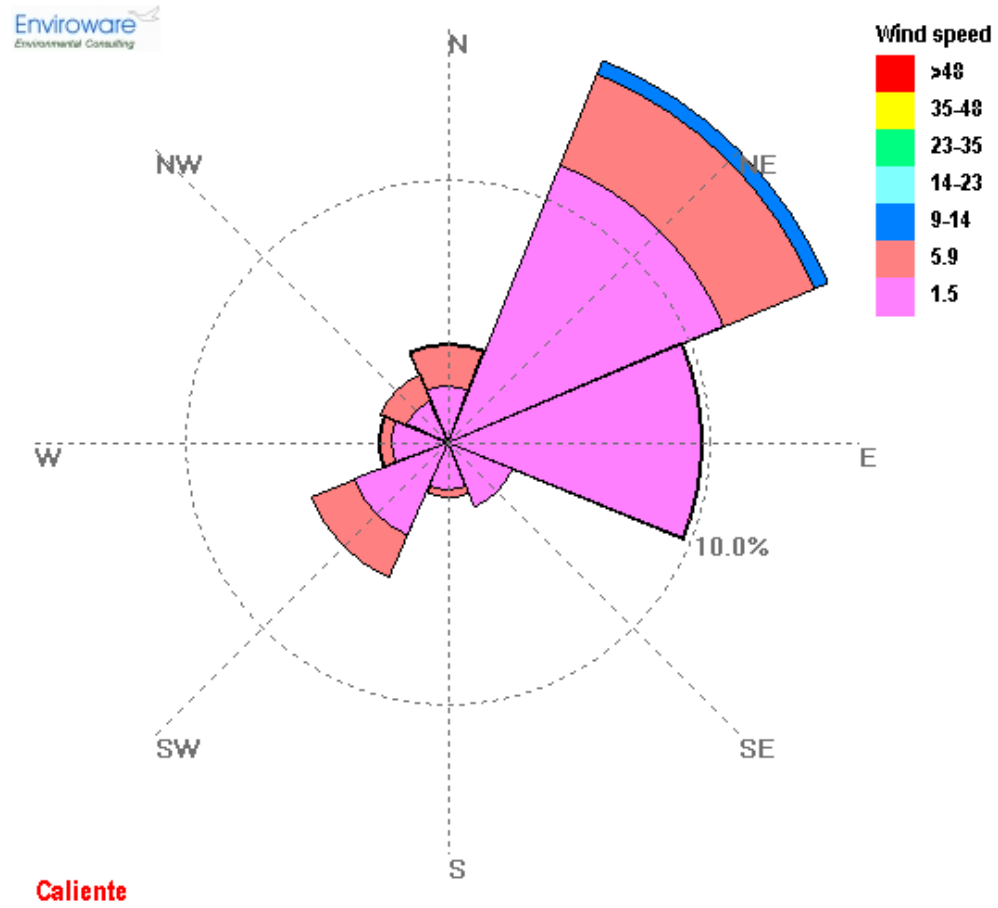

Figure 22. Wind direction and speed at Caliente.

For most of the monitoring period, prevailing winds were blowing from the northeast. This is to some extent controlled by the topography of the region. Lower wind speeds are recorded for winds blowing from the southeast (Figure 23).

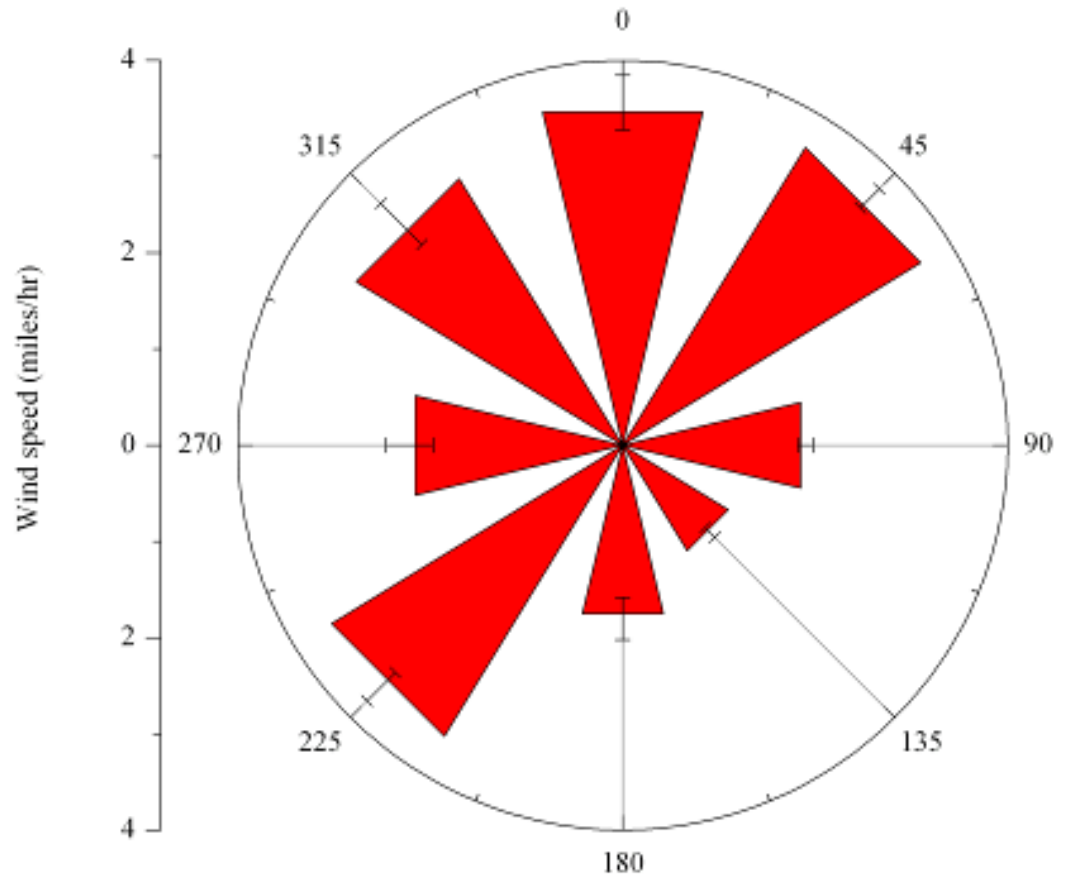

Figure 23. Average wind speed for each wind direction sector. Error bars represent the standard error of the mean. 


\section{Associations of Meteorology with Aerosol Measurements}

Trends and correlations of PM mass with meteorological conditions are shown for hourly TEOM data. A three-mode pattern is observed for both fractions of particle mass (Figure 24). The first mode is associated with comparatively higher particle mass

concentration in early morning (7:00 to 9:00 for $\mathrm{PM}_{10}$ and 10:00 to 11:00 for $\mathrm{PM}_{2.5}$ ) followed by a gradual decrease. The second mode for $\mathrm{PM}_{10}$, can be observed in early afternoon (13:00 to 15:00) as winds were increasing followed by an increase in the evening (19:00 to 22:00). There are significant differences of $\mathrm{PM}_{10}$ and $\mathrm{PM}_{2.5}$ concentrations for different wind directions, with substantially higher $\mathrm{PM}_{10}$ levels for northerly winds (Figure 25 and Figure 26).

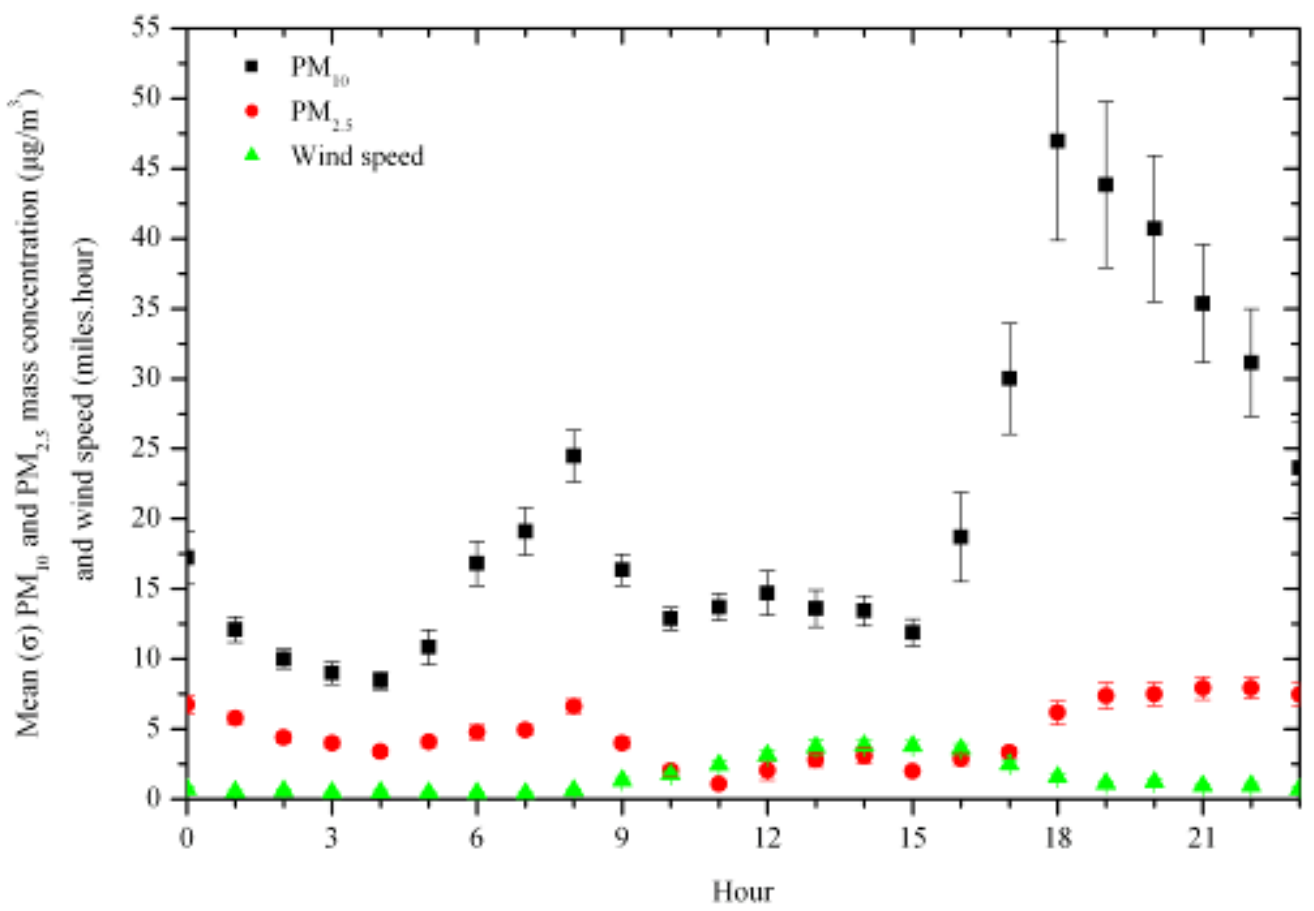

Figure 24. Hourly variation of $\mathrm{PM}_{10}$ and $\mathrm{PM}_{2.5}$ mass concentrations $\left(\mu \mathrm{g} / \mathrm{m}^{3}\right)$ as well as wind speed (miles/hour) at Site \#5 (Caliente). Error bars represent the standard error of the mean. 


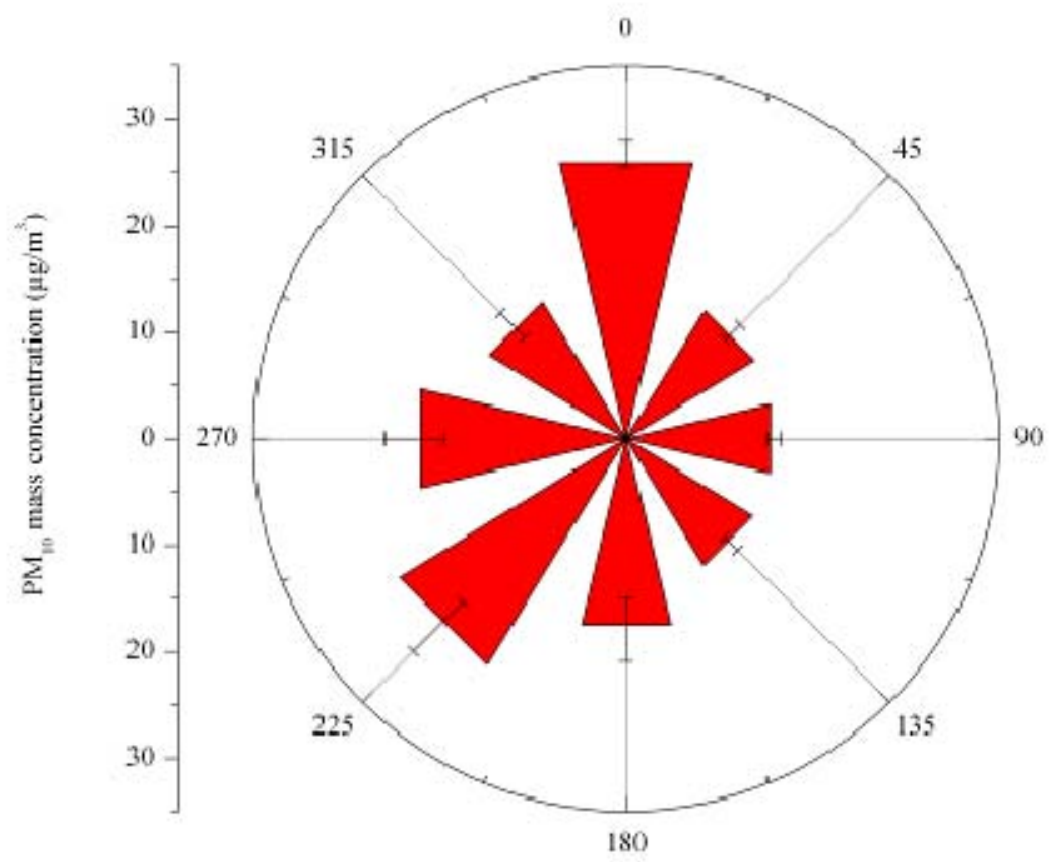

Figure 25. Mean ( \pm st.error) of $\mathrm{PM}_{10}$ mass concentrations $\left(\mu \mathrm{g} / \mathrm{m}^{3}\right)$ for different wind direction sectors at Site \#5 (Caliente).

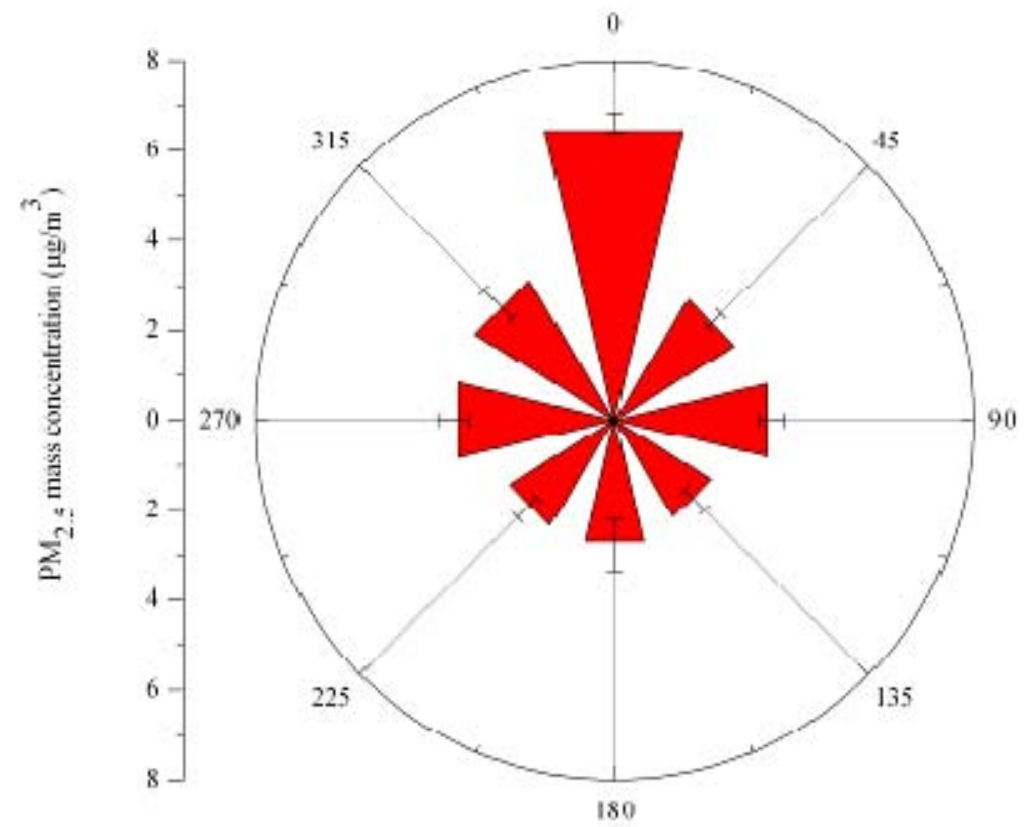

Figure 26. Mean ( \pm st.error) of $\mathrm{PM}_{2.5}$ mass concentrations $\left(\mu \mathrm{g} / \mathrm{m}^{3}\right)$ for different wind direction sectors at Site \#5 (Caliente). 


\section{CONCLUSIONS}

$\mathrm{PM}_{10}$ and $\mathrm{PM}_{2.5}$ mass concentrations and meteorological conditions were continuously monitored in Caliente from December 5, 2006, to February 15, 2007. Continuous measurements of $\mathrm{PM}_{10}$ and $\mathrm{PM}_{2.5}$ were obtained using both TEOM and DustTrak. At the same time, integrated samples of $\mathrm{PM}_{10}$ and $\mathrm{PM}_{2.5}$ were collected using FRM samplers on a 1-to-6-day schedule. Two sets of filters (December 7, 2006, and January 30,2007 ) were analyzed for major anions (sulfate, nitrate, chloride) and cations (sodium and potassium), elements (from sodium to uranium), and elemental and organic carbon. The comparison of $\mathrm{PM}_{10}$ and $\mathrm{PM}_{2.5}$ mass concentrations obtained by continuous monitors and filters showed that differences are associated with the limitations of the operating principle. For example, while light scattering (the measurement technique for DUSTTRAK) is not influenced by volatilization losses and is accurate for fine particles, it performs poorly for coarse particles, resulting in underestimation of $\mathrm{PM}_{10}$ mass by this method. TEOM $\mathrm{PM}_{10}$ measurements were subject to volatilization artifacts at relatively high $\mathrm{PM}_{10}$ concentrations. $\mathrm{PM}_{2.5}$ mass measurements obtained by TEOM, DUSTTRAK, and filter-based methods were comparable.

Mean 24-h concentrations of $\mathrm{PM}_{10}$ and $\mathrm{PM}_{2.5}$ mass were 20.5 and $4.9 \mu \mathrm{g} / \mathrm{m}^{3}$, which are significantly lower than the 24-h and annual NAAQS standards $\left(24-\mathrm{h} \mathrm{PM}_{10}: 150 \mu \mathrm{g} / \mathrm{m}^{3}\right.$, 24-h $\mathrm{PM}_{2.5}: 35 \mu \mathrm{g} / \mathrm{m}^{3}$; Annual $\mathrm{PM}_{2.5}: 15 \mu \mathrm{g} / \mathrm{m}^{3}$ ). Particle mass measured by filters varied from 3.2 to $31.4 \mu \mathrm{g} / \mathrm{m}^{3}$ for $\mathrm{PM}_{10}$ and from 1.9 to $8.7 \mu \mathrm{g} / \mathrm{m}^{3}$ for $\mathrm{PM}_{2.5}$. Higher $\mathrm{PM}_{10}$ and $\mathrm{PM}_{2.5}$ mass concentrations in the early morning and late afternoon. Substantially higher $\mathrm{PM}_{10}$ and $\mathrm{PM}_{2.5}$ levels were measured in early morning and evening. This is partially ascribed to local vehicle traffic during these hours. The chemical composition of both $\mathrm{PM}_{10}$ and $\mathrm{PM}_{2.5}$ samples indicated that soil is the major component of $\mathrm{PM}_{10}$ and organic carbon is mostly present in $\mathrm{PM}_{2.5}$. Sulfate and nitrate account for less than 10 percent. Increases in $\mathrm{PM}_{10}$ mass concentrations are associated with elevated concentrations of crustal material, while up to 8 $\mu \mathrm{g} / \mathrm{m}^{3}$ were unaccounted. This may be explained by water-bound particles as well as the neutralization of coarse nitrate by soluble calcium.

\section{ACKNOWLEDGEMENTS}

The authors thank Young's RV and Trailer Park in Caliente for hosting the trailer.

\section{REFERENCES}

Engelbrecht, J.P., I.G. Kavouras, D. Campbell, S.A. Campbell, S. Kohl, and D. Shafer, 2007a. Yucca Mountain Environmental Monitoring Systems Initiative. Air Quality Scoping Study for Ash Meadows National Wildlife Refuge, Nevada Letter Report DOE/NV/26383-LTR2007-01

Engelbrecht, J.P., I.G. Kavouras, D. Campbell, S.A. Campbell, S. Kohl, and D. Shafer, 2007b. Yucca Mountain Environmental Monitoring Systems Initiative. Air Quality Scoping Study for Beatty, Nevada Letter Report DOE/NV/26383-LTR2007-02

Engelbrecht, J.P., I.G. Kavouras, D. Campbell, S.A. Campbell, S. Kohl, and D. Shafer, 2007c. Yucca Mountain Environmental Monitoring Systems Initiative. Air Quality Scoping Study for Rachel, Nevada Letter Report DOE/NV/26383-LTR2007-03 
Engelbrecht, J.P., I.G. Kavouras, D. Campbell, S.A. Campbell, S. Kohl, and D. Shafer, 2007d. Yucca Mountain Environmental Monitoring Systems Initiative. Air Quality Scoping Study for Sarcobatus Flats, Nevada Letter Report DOE/NV/26383-LTR2007-04

Kavouras, I.G., V. Etyemezian, D. DuBois, J. Xu, M. Pitchford, and M. Green, 2005. Assessment of the Principal Causes of Dust-Resultant Haze at IMPROVE Sites in the Western United States. Final report to Western Regional Air Partnership (www.coha.dri.edu/dust).

Lefer, B.L. and R.W. Talbot, 2001. Summertime measurements of aerosol nitrate and ammonium at a northeastern U.S. site. Journal of Geophysical Research, 106, 20,36520,378 .

Malm, W.C., B.A. Schichtel, M.L. Pitchford, L.L. Ashbaugh, and R.A. Eldred, 2004. Spatial and monthly trends in speciated fine particle concentration in United States. Journal of Geophysical Research, 109, D03306, doi:10.1029/2006JD003739.

Malm, W.C., B.A. Schichtel, R.B. Ames, and K.A. Gebhart, 2002. A 10-year spatial and temporal trend of sulfate across the United States. Journal of Geophysical Research, 107, 4627, doi:10.1029/2002JD002107

White, W.H. and P.T. Roderts. 1977. On the nature and origins of visibility-reducing aerosol in the Los Angeles air basin. Atmospheric Environment, 11, 803-812. 


\section{DISTRIBUTION}

Allen Bensen

Yucca Mountain Project Office

Office of Civilian Radioactive Waste

Management

U. S. Department of Energy

1551 Hillshire Drive

Las Vegas, NV 89134

Jenny Chapman

Division of Hydrologic Sciences

Desert Research Institute

755 E. Flamingo Road

Las Vegas, NV 89119-7363

Linda Cohn

Environmental Protection Team

Nevada Site Office

National Nuclear Security Administration

U.S. Department of Energy

P.O. Box 98518

Las Vegas, NV 89193-8518

Lori Plummer

Environmental Protection Team

Nevada Site Office

National Nuclear Security Administration

U.S. Department of Energy

P.O. Box 98518

Las Vegas, NV 89193-8518

Marjory Jones

Division of Hydrologic Sciences

Desert Research Institute

2215 Raggio Parkway

Reno, NV 89512-1095

Peter Sanders

Environmental Restoration Project

Nevada Site Office

National Nuclear Security

Administration

U.S. Department of Energy

P.O. Box 98518

Las Vegas, NV 89193-8518
Reina Serino, Contracting Specialist

Office of Business Services

NNSA Service Center

Pennsylvania and H Street, Bldg. 20388

P.O. Box 5400

Albuquerque, NM 87185-5400

Connie Simpkins

Coordinator

Lincoln County Nuclear Waste Oversight

Program

100 Depot Avenue

Caliente, NV 89008

Bonnie Thompson

Water Resources, Nevada District

U.S. Geological Survey

160 N. Stephanie Street

Henderson, NV 89074

Nevada State Library and Archives

State Publications

100 North Stewart Street

Carson City, NV 89701-4285

Archives

Getchell Library

University of Nevada, Reno

DeLaMare Library/262

University of Nevada, Reno

Document Section, Library

University of Nevada, Las Vegas

4505 Maryland Parkway

Las Vegas, NV 89154

Library

Southern Nevada Science Center

Desert Research Institute

755 E. Flaming Road

Las Vegas, NV 89119-7363 
Public Reading Facility

c/o Nuclear Testing Archive

Nevada Site Office

National Nuclear Security

Administration

U.S. Department of Energy

P.O. Box 98521, M/S 400

Las Vegas, NV 89193-8521

(CD)

Technical Library

Nevada Site Office

National Nuclear Security

Administration

U.S. Department of Energy

P.O. Box 98518

Las Vegas, NV 89193-8518

(CD)
Office of Scientific and Technical Information U.S. Department of Energy

P.O. Box 62

Oak Ridge, TN 37831-9939

(electronic copy) 